$E$
51

N422

NMAI

V. 7 , no. 1 MUSEUM OF THE AMERICAN INDIAN

HEYE FOUNDATION

Vol. VII, No. 1

HENDRICKS-HODGE EXPEDITION

\title{
CIRCULAR KIVAS NEAR HAWIKUH NEW MEXICO
}

BY

F. W. HODGE

NEW YORK

MUSEUM OF THE AMERICAN INDIAN

HEYE FOUNDATION

1923 



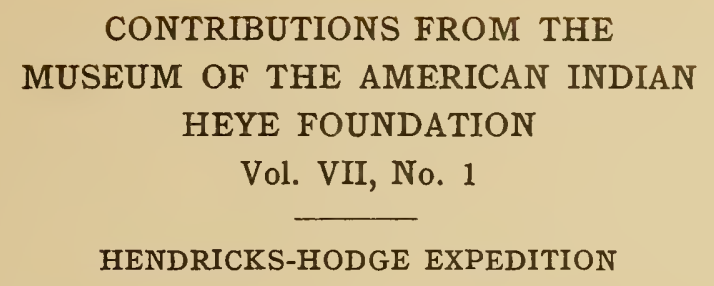

Vol. VII, No. 1

HENDRICKS-HODGE EXPEDITION

\title{
CIRCULAR KIVAS NEAR HAWIKUH, NEW MEXICO
}

\author{
$\mathrm{BY}$ \\ F. W. HODGE
}

NEIV YORK

MUSEUM OF THE AMERICAN INDIAN

HEYE FOUNDATION

1923 



\section{CONTENTS}

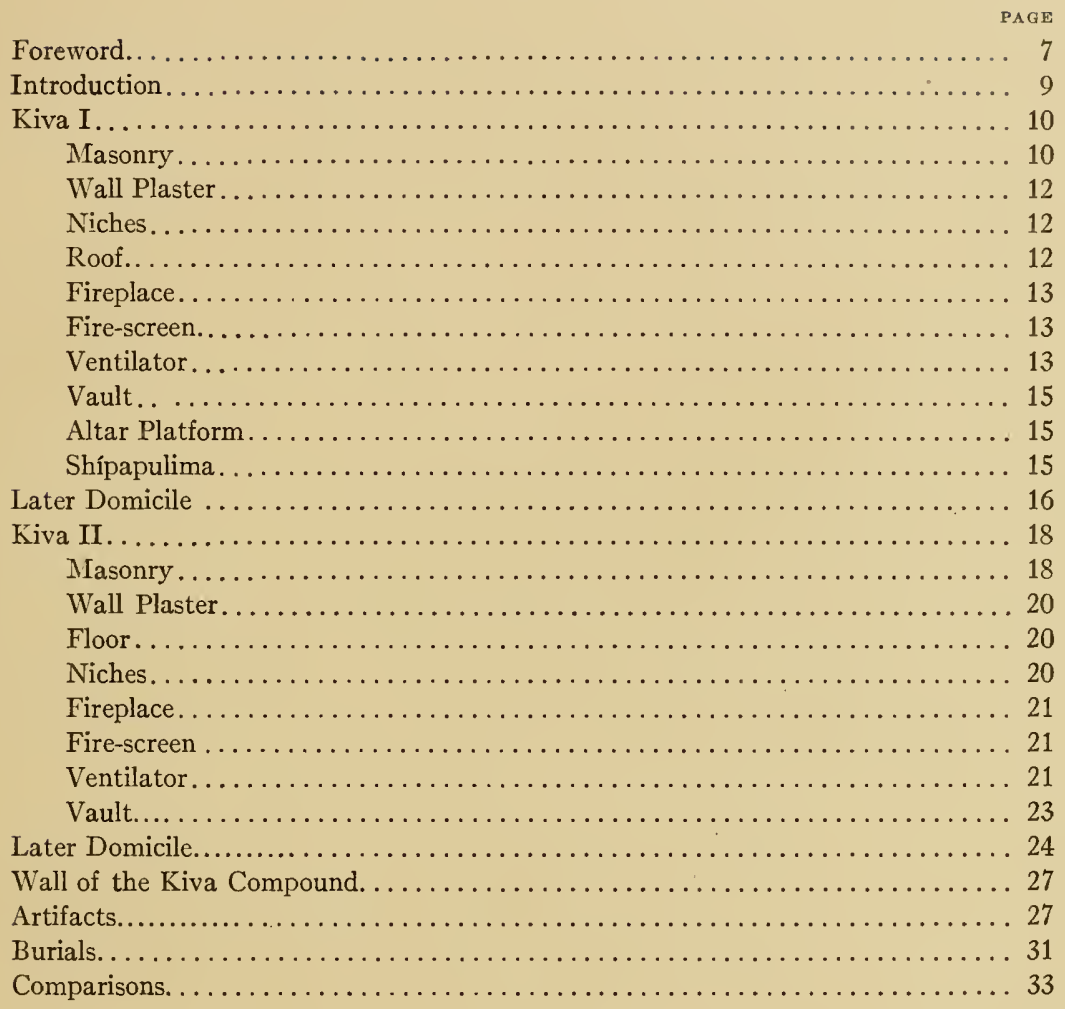





\section{ILLUSTRATIONS}

Plates

I. Ground-plan of the circular kivas $\ldots \ldots \ldots \ldots \ldots \ldots \ldots \ldots \ldots \ldots \ldots \ldots \ldots$

II. Looking southwestwardly across the two kivas................ 10

III. Kiva I after the removal of the later domicile, looking westwardly.... 11

IV. Looking westwardly across Kiva I to Kiva II. ................. 12

V. Kiva I, looking southwardly from the fireplace to the flue beyond the wall. 13

VI. Kiva $I$ in its relation to the later structure built within its walls, looking southwestwardly ............................... 14

'VII. Part of the main wall of Kiva I, with the buttress wall and its easterly niche, the altar platform, and the shípapulima............. 15

VIII. The shipapulima of Kiva I. . . . . . . . . . . . . . . . . . . 16

IX. The recent room built above the floor of Kiva $I$ and against its northwestern arc ................................. 17

$\mathrm{X}$. Interior of the small room within Kiva I, looking south $\ldots \ldots \ldots \ldots 18$

XI. The two kivas, looking eastwardly toward the Hawikuh knoll ......... 19

X.II. Looking southwardly across Kiva II, with a part of Kiva I at the left. . 20

XIII. Looking northwardly across Kiva II from its later ventilator flue..... 21

XIV. Ventilator shaft and flue of Kiva II, looking south............. 22

XV. Kiva II before the removal of the small house built within it. Looking

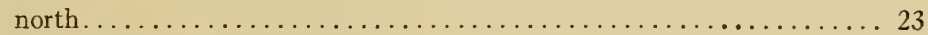

XVI. Kiva II before the removal of the small house built within it. Looking southeast..................................... 24

XVII. North wall of the compound, with Kiva I at the left and the site of Kiva II before excavation........................... 25

XVIII. The north wall of the compound, with Burial 7 outside.......... 26

XIX. Mealing-bins in juxtaposition with the outer wall of Kiva I . . . . . 27

XX. Fragments of vessels of black-on-gray ware................. 28

XXI. Fragments of vessels of black-on-gray and of black-on-red ware...... 29

XXII. Deep corrugated bowl of the finer class, and part of a jar with corrugated

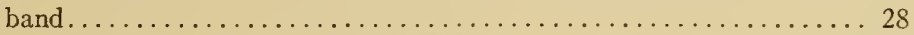

XXIII. Fragments of vessels of corrugated ware................... 29

XXIV. Deep bowl of black-on-gray, bowl of faded greenish glaze on cream, and fragment of bowl with black glaze on red ................ 30

XXV. Parts of bowls with black-on-red decoration................. 31

XXVI. Sherds showing black glaze on red, early green glaze on reddish, and black-on-red.............................. 32

XXVII. Two bird-shape vessels, a crude jar with opening ground in side, and a crude cup.....................................33

XXVIII. Early polychrome bowls, a canteen with purplish glaze on creamy slip, and a pitcher of black-on-gray......................... 34

XXIX. Vessels of late glaze and of early polychrome................ 35

XXX. A crude jar of corrugated ware and a scoop or dipper ground from a bowl sherd of recent glaze ware ......................... 36 


\section{ILLUSTRATIONS}

\section{Figures}

PAGE

1. Pendant of white stone in the form of a human foot $\ldots \ldots \ldots \ldots \ldots \ldots \ldots 31$

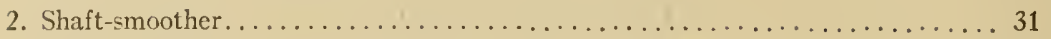

3. Burnt deer-bone carved to represent a grotesque head. . . . . . . . . . . 32

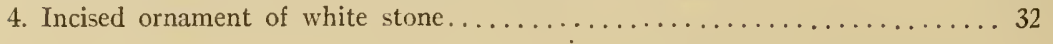




\section{FOREWORD}

T T IS deemed advisable to publish the present paper without awaiting for the presentation of the final report on the excavation of the ruined pueblo of Hawikuh, for the reason that the circular kivas described are pre-Hawikuh in type and structure, and therefore bear only incidental relationship to that former Zuñi settlement.

Readers of preceding papers on the Hawikuh investigations are already aware that it is owing to the interest of Harmon W. Hendricks, Esq., a trustee of the Museum of the American Indian, Heye Foundation, that the researches of the Hendricks-Hodge Expedition were made possible; therefore, whatever value the present article and the results ultimately to be published may have to Pueblo archeology, will be due to Mr. Hendricks' interest and to the generous manner in which he has supported the work and planned for the publication of the facts derived therefrom.

F. IV. Hodge

NEW YORK

March 22, 1923 





\section{CIRCULAR KIVAS NEAR HAWIKUH, NEW MEXICO}

BY

\section{F. W. HODGE}

\section{INTRODUCTION}

I

CONDUCTING the excavation of the ruins of the Zuñ pueblo of Hawikuh, it was somewhat surprising to find, at a distance of 656 feet bearing westwardly $102^{\circ}$ from the northwest corner of the house group, the remains of two circular kivas which bore only an incidental relation to Hawikuh itself. These kivas were encountered by mere accident, as there were no surface indications of their existence, excepting the occurrence of various spalls of stone such as are present at other points in the vicinity.

Late one evening an Indian workman, while hunting rabbits at the foot of the slope on which the camp of the HendricksHodge Expedition was situated, and a few hundred feet southwest thereof, reported the fresh unearthing of a human toe-bone by a prairie-dog, and examination the next morning, followed by excavation, resulted in exposing the entire skeleton several feet away, lying adjacent to a low stone wall (Burial 1 on the plan). Continuing the excavation, this exposed wall was found to connect with other walls, which in turn were uncovered. Ultimately a circular chamber was exposed, and, adjacent to it, another, the two having been bounded on three sides, at least, by a wall, with remains of dwellings intervening (pl. I. II). Surface potsherds were absent, having either been gathered by Hawikuh women for use in tempering their pottery, or been covered by wash from the slope of the rise immediately north of the site, or both. Beneath the surface, however, sherds were fairly abundant.

It was evident from the beginning that these kivas bore only an incidental relation to the pueblo of Hawikuh, that indeed they were relics of a culture quite different from that of the Zuñi people who built and inhabited that nearby village, for to them the cir- 

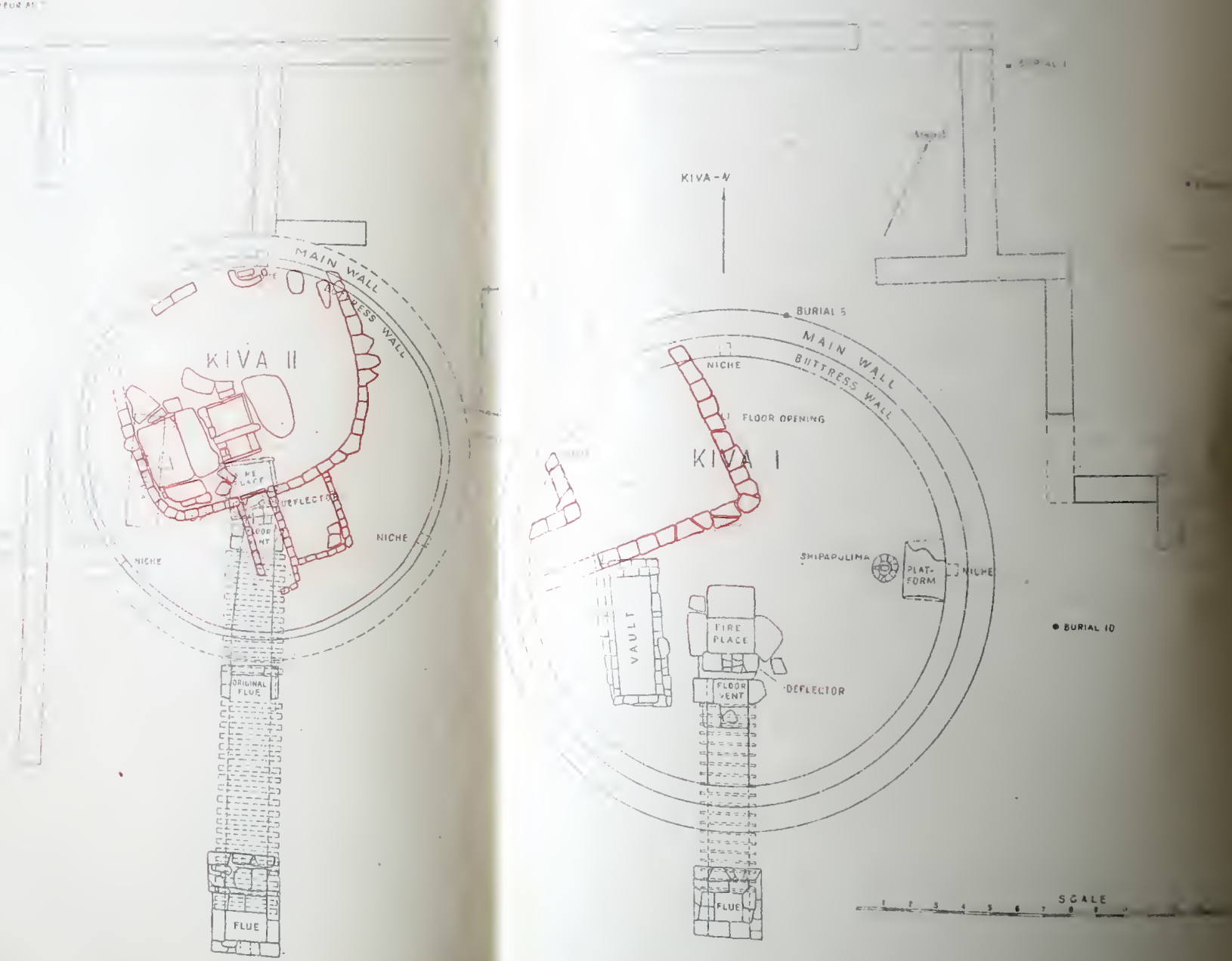



$$
\text { (Surveyed by E. Fi Co A }
$$


- buaral 3

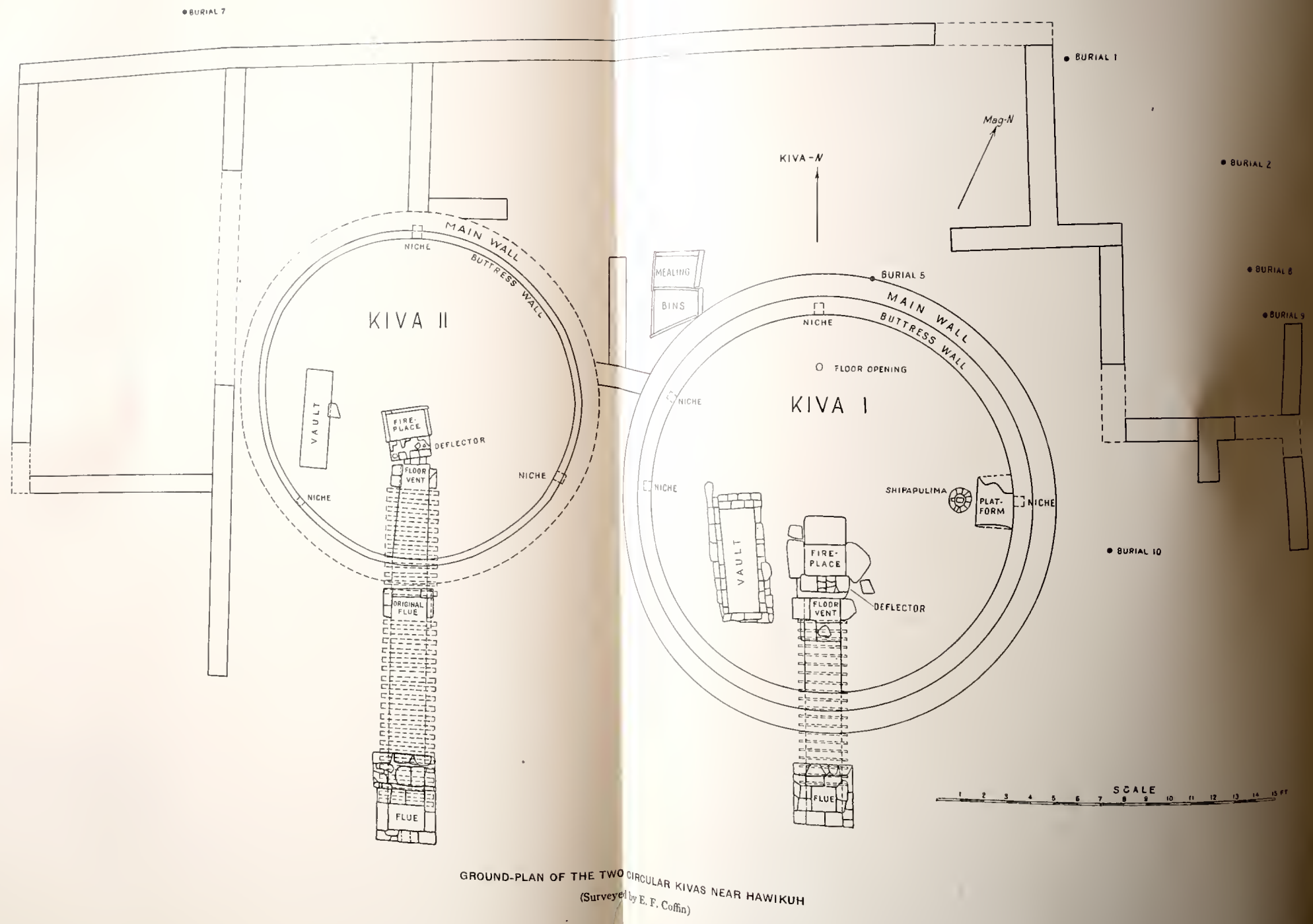


cular form of kiva was unknown either in ancient or in modern times; in fact, it became more and more manifest, as excavation progressed, that these structures were erected by a pre-Hawikuh and indeed a pre-Zuñi people. The incidental relation of the kivas to Hawikuh was not in the original buildings themselves, but was due to the facts (1) that the readily available stones used in the construction of the upper walls of the kivas had been gathered by the Hawikuh inhabitants and used in house-building; (2) that these later dwellers partly excavated both of the kivas and built a small rude room within each; and (3) that they buried some of their dead within or near the kiva compound. All this occurred during the earlier period of Hawikuh, but after the abandonment of the kiva site. We may mention here that there are no visible remains of dwellings beyond the kiva compound, and none on the higher land in the juniper grove a few hundred yards north of Hawikuh, where, scattered over the surface, are thousands of sherds of the same types of pottery (black-on-gray, black-on-red, and varieties of excellent corrugated ware) as were found in the undisturbed débris filling the two kivas. A number of pre-Hawikuh graves have been encountered near this site, and others have been found at intervals between camp and the kivas. The same conditions prevail at an ancient site known to the Zuñi as Túmataptan, at the southern end of a sandy promontory perhaps four miles west by north from Hawikuh, across the Zuñi river, where superficial examination showed no evidence of the existence of kivas or of domiciles, save for a fireplace on the surface without accompanying house walls. From this it may be assumed that aside from what were doubtless stone dwellings within the kiva compound, the domiciles of the builders of the circular kivas at Hawikuh were of a temporary and perishable character, such, perhaps, as wattle-and-daub.

\section{KIVA I}

Masonry.-The kivas, and especially that designated as Kiva I (see the plan, pl. I), were far better examples of masonry than were any of the Hawikuh buildings. Kiva I (pl. III) was almost perfectly circular; indeed it did not vary more than half an inch in its 


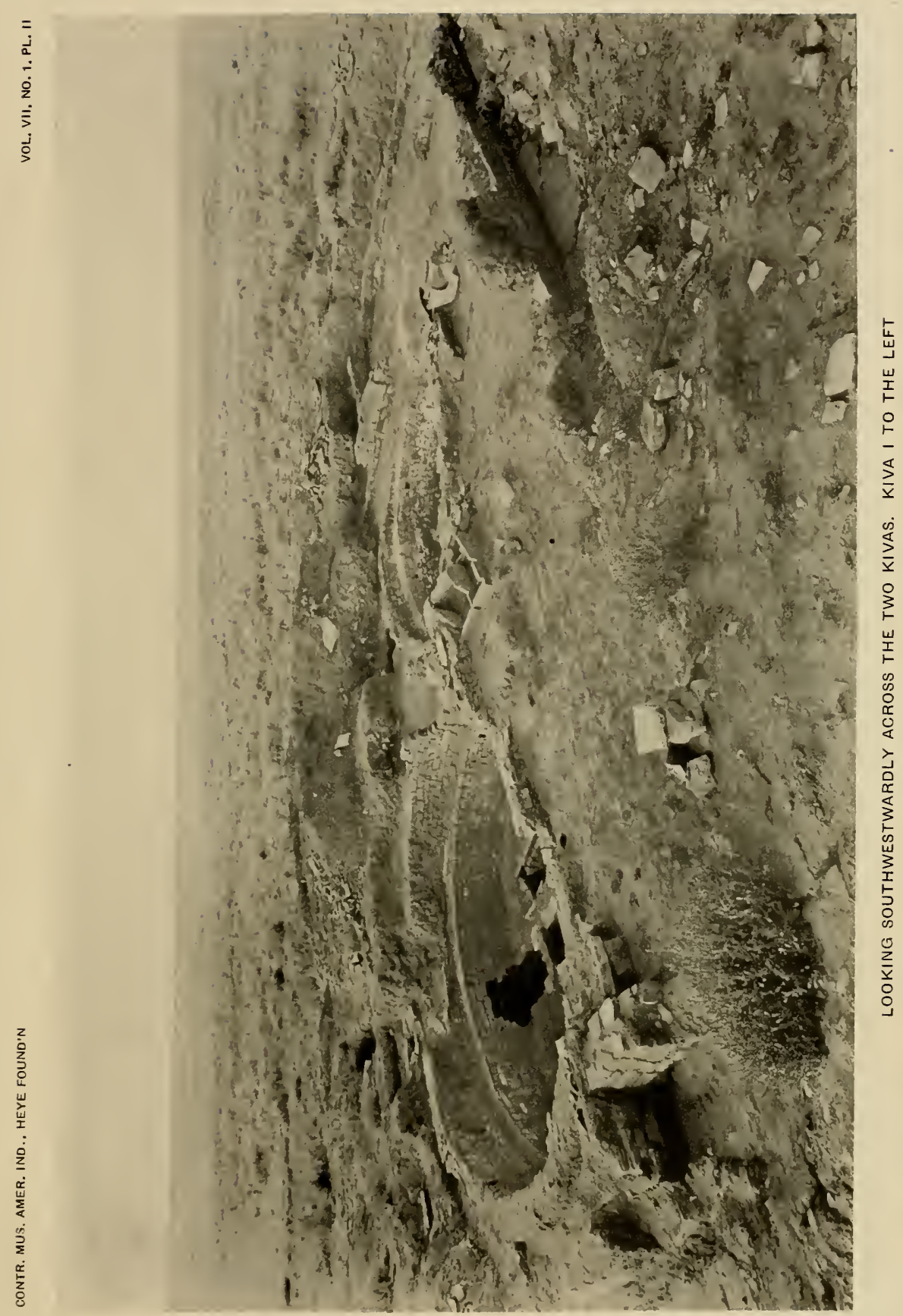




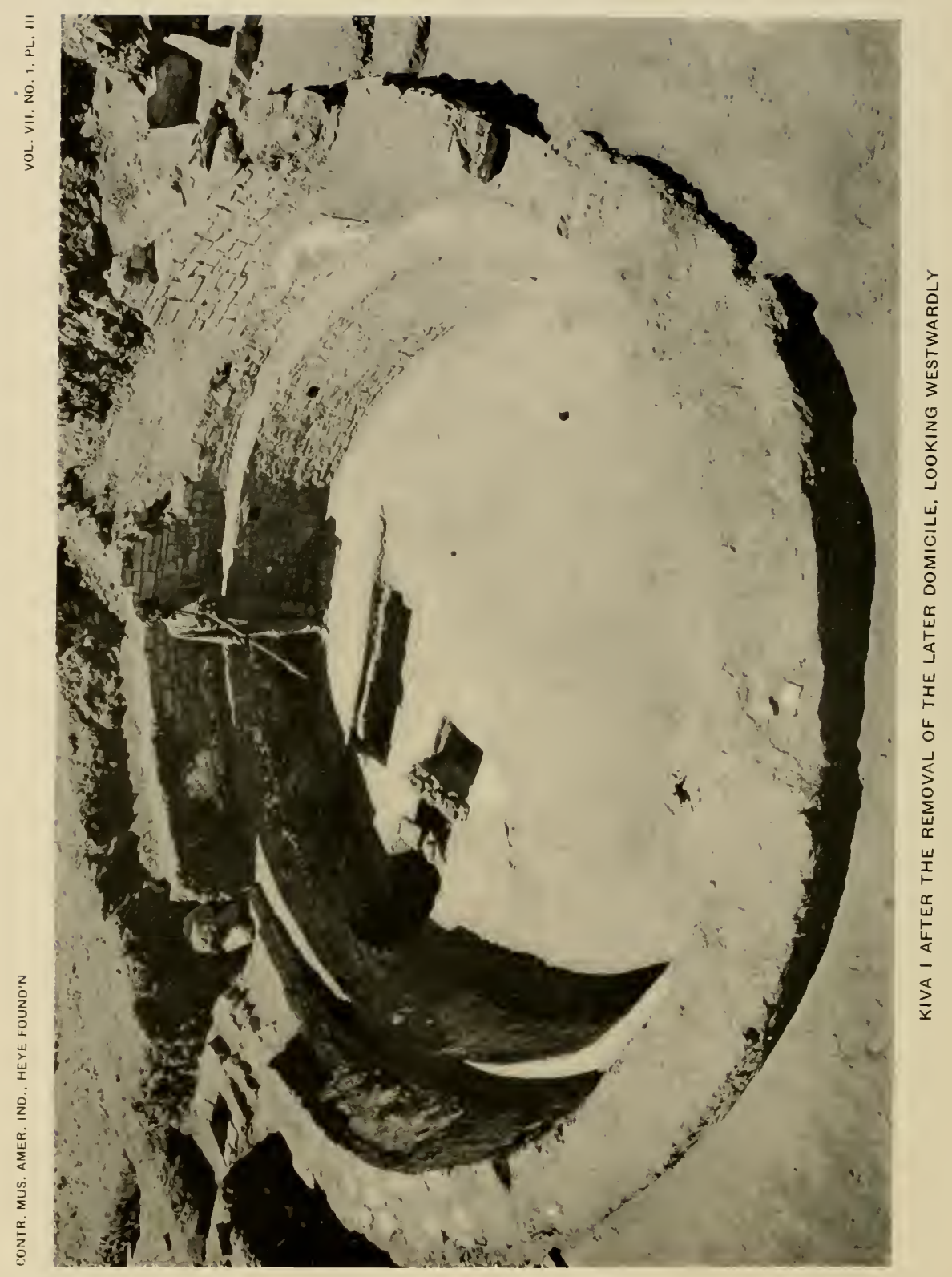


diameter of 17 feet, measured at several points within the chamber. To construct a building so symmetrical as this must have necessitated the use of a taut string in laying out the circular groundplan from the center, for no such exactness could have resulted from mere eye-work. Even in the more diminutive dwellings of Hawikuh, where the eye alone was doubtless used in determining the ground-plan of a proposed house, a truly rectangular structure has not been found among the 286 chambers thus far uncovered.

The masonry of Kiva I was of superior character, save for the breaking of the joints. Indeed in no masonry of the Pueblo region known to the writer, regardless of the excellence of the walls in other respects, did the builders display knowledge of the need of not having a joint in one course of masonry in vertical alignment with the joints of adjacent courses. (To this day Zuñi builders have never learned this simple rule of construction.) Nevertheless, there was no indication in the wall of Kiva I that failure to break joints resulted in weakness, partly because of the reinforcement of the main wall by the narrower inner buttress wall and the fact that the entire structure was more enduring by being circular, and also for the reason that the kiva was largely underground and surrounded by very compact clayey soil. At any rate, that part of Kiva I which still stood was practically perpendicular (pl. IV).

The inner or buttress wall referred to bore a certain correspondence to the "bench" in kivas of the territory drained by the San Juan, to which reference will later be made; it was found to be of a maximum height of 2 feet 8 inches above the floor, and had been capped with more or less smooth slabs of sandstone, somewhat thinner than those used in the wall itself, covered with a thin coat of adobe plaster. Its width was 10 inches throughout most of its course, but narrowed to $9 \frac{1}{2}$ inches at a few points. The masonry of the outer or main wall, so far as exposed, was of similar character, and averaged 12 inches in thickness.

As above intimated, a considerable part of the upper main wall of Kiva I had been removed, no doubt by the builders of Hawikuh, when the fallen stones on the surface became exhausted, showing that in all probability the abandoned kiva was well advanced in decay and the chamber filled with fallen masonry and drifted sand 
and soil when the first houses of Hawikuh were built. A section of the main or outer wall at the east had been removed entirely to the level of the thinner buttress wall, while at other points stones from the main wall had likewise been taken away, although to a lesser extent. The highest part of the masonry was the northwestern section, its height here being 4 feet above the buttress wall, or 6 feet 8 inches above the floor (pl. III). Probably this was due to the building of the domicile by people of Hawikuh, before alluded to, as this higher part of the kiva wall formed the outer wall of the later chamber (pl. vi). Further reference to this room will be made later.

Wall Plaster.-The inner face of the surrounding wall, both above and below the top of the buttress, had received several applications of thin plaster. The original coat was of adobe of natural color, and at least two or three similar coats were subsequently applied at intervals before a wash of white (presumably gypsum) was given, then alternate coatings of adobe and gypsum, and finally, at the time the kiva was abandoned, its walls were again of adobe color. Where best preserved the maximum thickness of the plaster was nearly half an inch.

Niches.-There were four niches in the buttress wall of the kiva, three of them rectangular and approximately at the north, east, and west cardinal points, respectively, and the fourth, rounded by plastering, between those of the north and west. There was no niche at the south, where the air-duct of the kiva had its opening, as will later be described. To be exact, the niches were of the following dimensions: Northern, 5 inches wide, $4 \frac{1}{2}$ inches high, $5 \frac{1}{4}$ inches deep; 1 foot 5 inches above the floor. Eastern, $5 \frac{1}{2}$ inches wide, $4 \frac{1}{2}$ inches high, $5 \frac{1}{2}$ inches deep; 2 feet $1 \frac{1}{2}$ inch above the floor. Western, $5 \frac{1}{2}$ inches wide, $4 \frac{1}{2}$ inches high, $5 \frac{1}{2}$ inches deep; 2 feet above the floor. Northwestern, $4 \frac{1}{2}$ inches wide, 4 inches high, $5_{4}^{1}$ inches deep; 1 foot 9 inches above the floor.

Roof.- No trace of roof-beams was found in the débris, which so entirely filled the structure as to leave not even a depression in the surface. It is hardly likely that junipers, which still grow abundantly in the vicinity, could have supplied the timbers necessary for roofing a chamber nearly 20 feet in outer diameter, conse- 


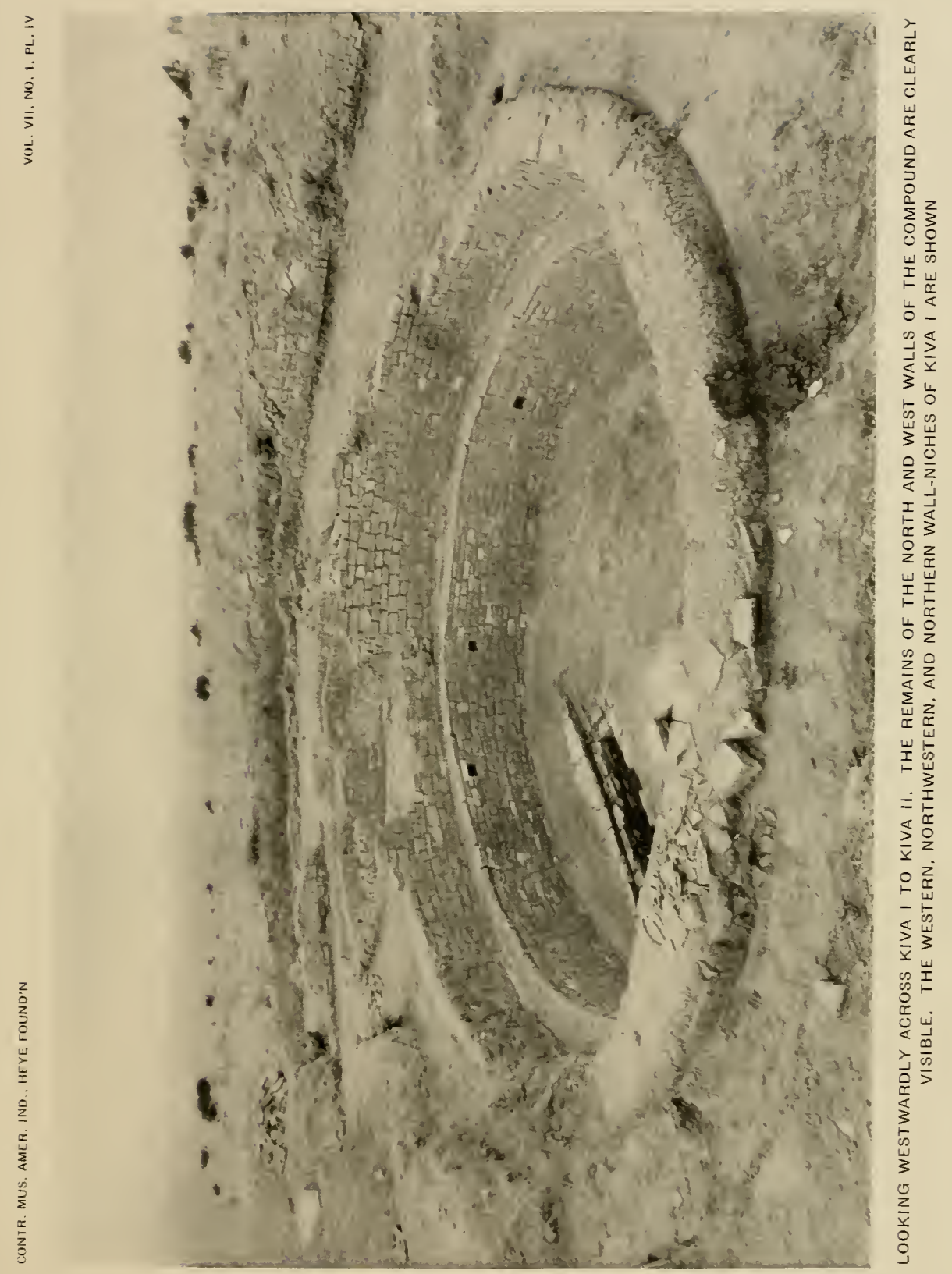




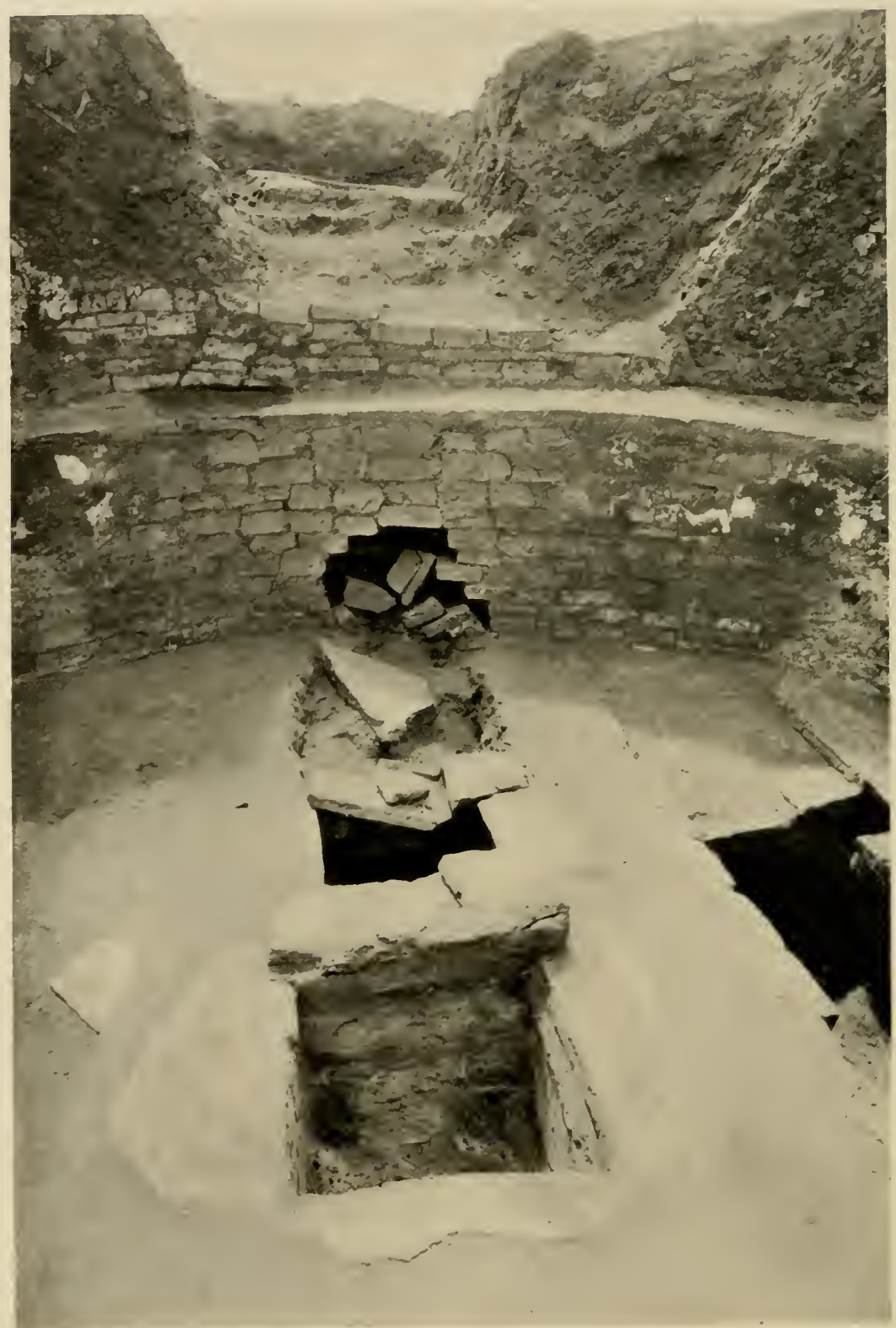

KIVA I. LOOKING SOUTHWARDLY FROM THE FIREPLACE TO THE FLUE BEYOND THE WALL 
quently the builders of the kiva doubtless resorted to the same expedient as the priests of Hawikuh in roofing their great rectangular kiva in the plaza of that pueblo, namely, of carrying beams of pine from a distance of at least eight miles up the cañon eastward from the present farming village of Ojo Caliente, or about eleven miles from the kiva site, that being the nearest point where pines of sufficient size for such roof construction are found. An insignificant fragment of what may have been a roof-beam, far advanced in decay, was found at the floor of Kiva II.

In neither kiva were there evidences of depressions in the floor or on the buttress wall, such as might have held posts for the support of the roof; but in Kiva I, 2 feet $3 \frac{1}{2}$ inches from the north niche, there was a round opening, $3 \frac{1}{2}$ inches in diameter and 8 inches deep, which may possibly have borne some relation to a loom-frame or an altar.

Fireplace.-South of the center of the kiva was the fireplace, distant 1 foot $10 \frac{1}{2}$ inches to its northern edge. Compared with the fireplace in the Hawikuh houses, this one was large, measuring 1 foot $10 \frac{1}{2}$ inches E-W by 1 foot 5 inches $\mathrm{N}$-S, by 1 foot $1 \frac{1}{2}$ inch in depth. Its sides were formed of slabs of stone set on edge and fastened in place with adobe mortar; its top was surrounded by flagging placed at floor level (pl. v). The cavity was well filled with fine ashes. This fireplace hạd been burrowed into by prairiedogs, which marmots, while doing considerable damage to the contents of certain Hawikuh graves, more than compensated for these depredations by revealing archeological remairs of which there had been no surface indications.

Fire-screen.-Rising from the southern side of the fireplace and extending beyond its edges about two inches was a low wall, the fire-screen or "deflector," 2 feet $2 \frac{1}{2}$ inches long, 8 inches wide, and 6 inches in maximum height, but slightly broken down. It was built of stones and adobe, and stood on one of the flagstones surrounding the fireplace.

Ventilator.-Next in order southward was the ventilator pit, with a space of four inches separating it from the fire-screen. This pit was not in alignment with the fireplace, as the photograph and plan show. The pit opening had probably measured 1 foot $5 \frac{1}{4}$ 
inches E-IV by 11 inches N-S, or less than the dimensions of the pit itself, because of the flagging at its eastern and western rims, the latter overhanging the pit three inches. The width of the pit cavity was uniformly 1 foot 8 inches, and its depth below floor level 2 feet 1 inch. Excepting this permanent opening, the airduct, which passed southward through and beyond the kiva wall, had been covered entirely with stone slabs supported (between the ventilator opening and the kiva wall) by transverse sticks about an inch in diameter, which rested on the ventilator walls $7 \frac{1}{2}$ inches to 8 inches below floor level. Over the remains of these supporting sticks were pieces of spit wood, which in turn were covered with smaller sticks, like withes, and then a coating of mud, on which the flagstones were set, their length extending E-IW (pl. v).

As mentioned, the duct passed through the kiva wall and beyond it for a distance of 5 feet 7 inches, making its total length 9 feet 8 inches from the opening in the floor. The collapse of the covering slabs of the duct caused some of the stones of the kiva wall immediately above (i.e., where the duct entered the wall) to fall, but there is little likelihood that a niche corresponding with the niches in the north, east, and west arcs of the buttress wall existed here. From the end of the horizontal duct, beyond the kiva wall, rose the vertical shaft or flue, measuring inside 1 foot 5 inches $\mathrm{N}$-S, by 1 foot 8 inches E-W at the bottom, and reaching the surface at a height of 6 feet 2 inches, where it was 1 foot 2 inches square. As exposed at the surface (pl. III, v) the thickness of the masonry of the shaft varied from $7 \frac{1}{2}$ inches in the south wall to 12 inches in the north wall; the others measured (E) 9 inches and (W) 10 inches in thickness. The top of the shaft was 1 foot 6 inches below the surrounding surface, which may or may not have been the depth of the natural fill, as it was not determinable whether the upper stones of the shaft, like those of the main wall of the kiva, had been taken by the Hawikuh people for building purposes. The space between the upper shaftopening and the kiva wall was filled with rubble.

It has been suggested that the entire structure here described as a ventilator may have served the purpose in kivas generally 


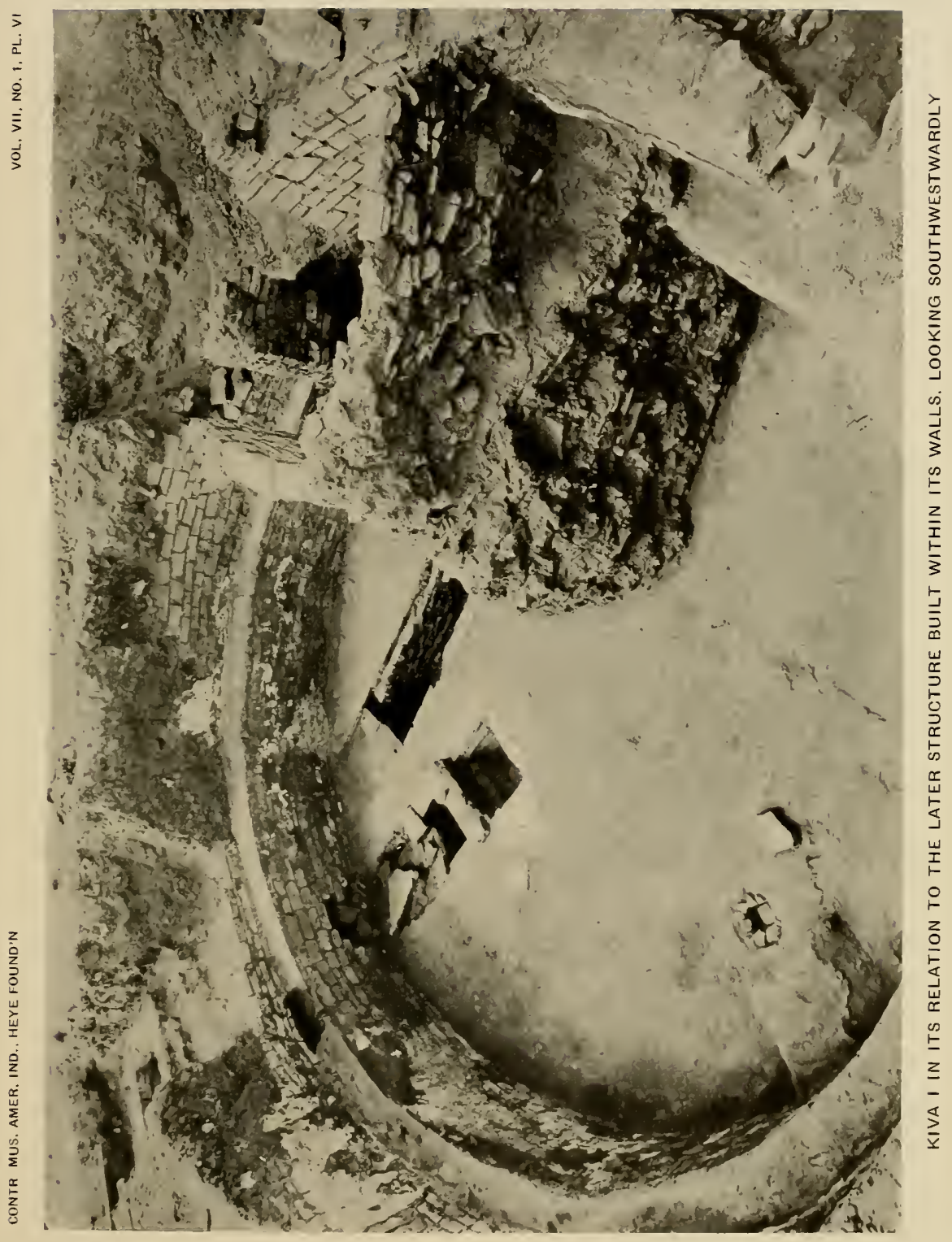




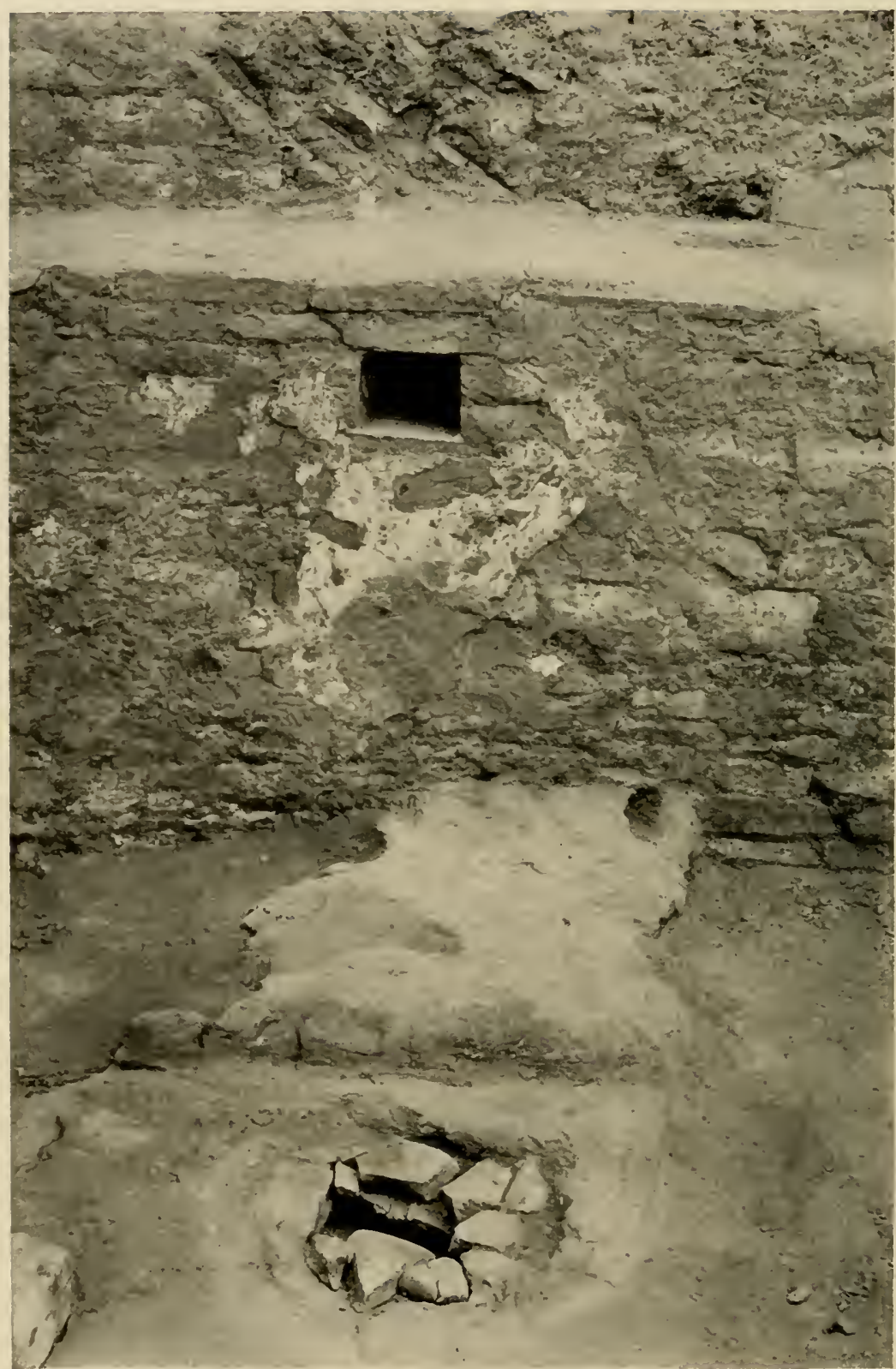

PART OF THE MAIN WALL OF KIVA I. WITH THE BUTTRESS WALL AND ITS EASTERN NICHE. THE ALTAR PLATFORM, AND THE SHIPAPULIMA 
of a more or less secret passage; but it can hardly be conceived that in the case of the ceremonial chambers under discussion, at least, these vents could have been designed for such use, since the flue of Kiva I measured only 14 inches square at the surface, not to mention the floor opening, which was 11 by 17 inches. It was possible for some of our attenuated Zuñi workmen to crawl through the outer vent, but for others this was impossible.

Vault.-A feature of Kiva I was a rectangular box-like structure below the floor, its greater dimension extending N-S at a maximum distance of 3 feet 8 inches from the western wall (pl. III-v). Its upper edges were of stones set at floor level, excepting at the northern and southern sides, which were slightly depressed. Below these upper stones of the eastern and western edges, from $2 \frac{3}{4}$ inches to $4 \frac{1}{2}$ inches below the floor, were the tops of inner walls, $2 \frac{1}{2}$ inches wide, that extended downward 1 foot 6 inches to the bottom of the vault, forming a ledge on which had rested the cover slabs found broken within. The northern wall of this little chamber was double, its inner member rising only 9 inches above its floor, or half the height of the other. The total inside length of the structure was 5 feet 2 inches, and its width 1 foot 9 inches at the northern and 1 foot 6 inches at the southern end. It appeared as if it had been intended by the builders to make the vault longer, as there was a depression in the kiva floor extending southward from it to the kiva wall, and a similar depression northward for a distance of 2 feet 3 inches, in each case the exact width of the pit. Further reference to this vault will be made.

Altar Platform.-Rising from the kiva floor, its center below the eastern niche above described, was a low adobe platform with rounded edges (pl.vir), which had measured about 1 foot 6 inches at its northern and 1 foot 8 inches at its southern side, by 2 feet 5 inches at the eastern or wall side, and 2 feet 2 inches at the front or western edge. The platform, which in all probability was the permanent feature of the altars before which rites were performed, was only 3 inches in height, and the edges were partly broken away, probably by the burrowing of prairie-dogs.

Shipapulima.-Immediately in front of this low platform, and only eight inches from it to the middle of the opening, was the 
shipapulima (the Zuñi equivalent of Hopi shipapu), the orifice symbolizing the mythic place of emergence and of departure of the shades of the dead, a feature so characteristic of Pueblo kivas. This device, irregularly $2 \frac{1}{2}$ inches square, was pecked in a sandstone slab, found broken in two, set four inches beneath the floor (pl. viII, $b$ ). Surrounding the shipapulima at floor level were a number of stones of irregular shape and more or less loosely placed, that formed the top or coping of a diminutive wall of masonry exposed in the depression between the floor and the shipapulima opening. The orifice itself was covered with a shaped stone having more or less rounded edges, and measuring $3 \frac{1}{2}$ inches by 4 inches in diameter, by five-eighths of an inch thick; its longer diameter was E-W over the opening (pl. virI, a).

Removing its upper and the lining stones, the shípapulima was found to extend 1 foot 4 inches beneath the floor, and its wall, instead of being rertical, receded toward the base, so that while the upper part surrounded a space of 11 inches diameter, the width at the bottom was only 5 inches to 6 inches. The seven stones forming the lining were approximately $1 \frac{1}{2}$ inches in thickness, were roughly of keystone shape, and were set on end (pl. viII, $c$ ).

The base of the shipapulima was a flattish stone of unknown size, probably bedrock, in the middle of which a cuplike depression, 3 inches in diameter and 2 inches deep, had been pecked, as shown in pl. vIII, $d$.

\section{Later Domicile}

The features of this ancient kiva having been described in detail, we may now give attention to the rather rude structure that had been built within it in comparatively recent times, that is, after the abandonment of the kiva and about the time Hawikuh was first settled, as will later be seen.

By examination of the plan and of pl. vi and $\mathrm{Ix}$, it will be observed that this enclosure occupied approximately the northwestern quadrant of the kiva, its inner northeastern corner being 2 feet 3 inches west of the north niche before described. Although its builders had excellent and ready material at their command, the workmanship was inferior to that of the better walls of Hawikuh, 

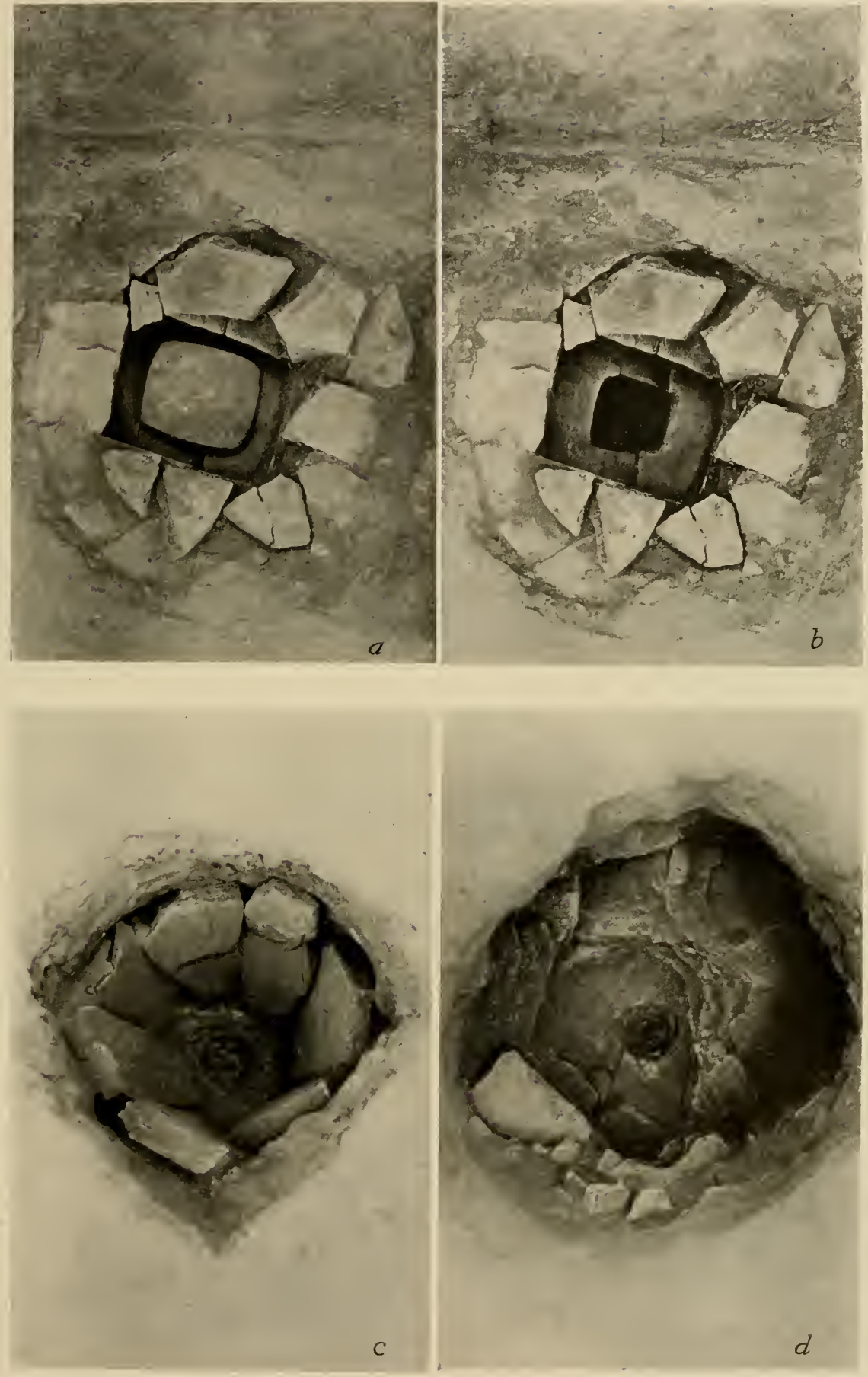

THE SHIPAPULIMA OF KIVA I

$a$, The orifice with its cover in place. $b$, The orifice with the cover removed. $c$, The stone lining of the sides. $d$, The bedrock bottom after the removal of the sirle slabs. 


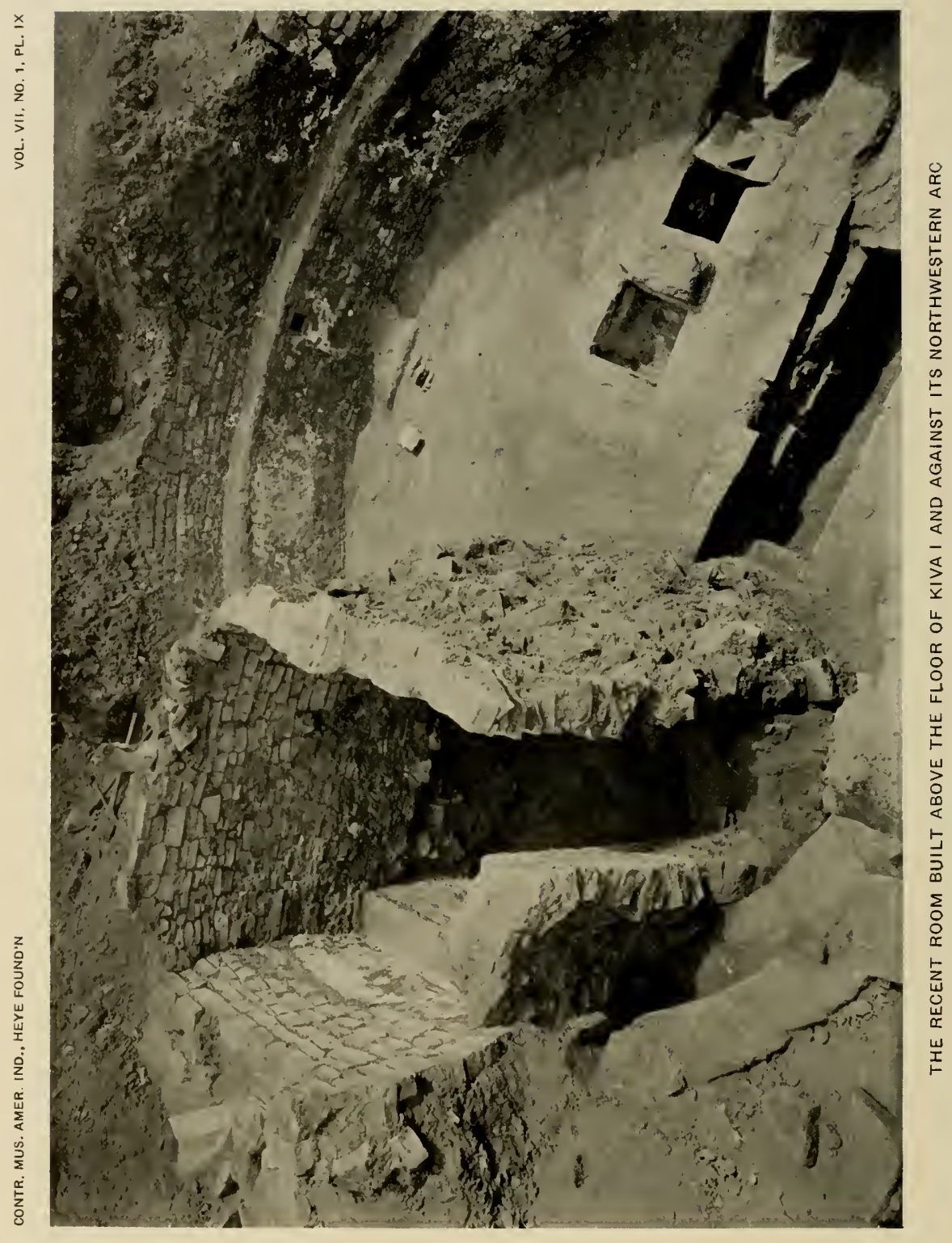


and far inferior to the masonry of the kiva in which the house was erected. There is no doubt that this building was constructed of stones from the fallen kiva walls, from the upper courses of its standing walls, as hitherto mentioned, or from the wall that once partly enclosed the kiva compound. That this building, as well as the one erected within Kiva II, was a dwelling, there is little doubt, although the former had no fireplace, perhaps because occupied only at convenient intervals.

The masonry of the south wall of the house especially showed such liberal use of adobe mortar that it had squeezed from the joints when the stones were laid. The southeastern corner of the room indicated a rude attempt at bonding ( $\mathrm{pl} . \mathrm{x}$ ). The average thickness of the walls was only 8 inches, whereas in Hawikuh the house walls averaged 11 inches.

The walls of the room did not extend to the kiva floor, but were erected on a deposit of drifted sand, washed-in earth, and fallen building stones, 2 feet 5 inches deep. This, of course, did not represent the total depth of the kiva fill at the time the little house was built, for in order to reach the desired depth and to provide what had been at least a partly subterranean domicile, an excavation in the fill was made by its builders and the walls erected against the vertical earthen sides; as is well shown in pl. vI, which illustrates not only the rear or unexposed face of the eastern wall of the room and the refuse beneath its rude masonry, but proves that the kiva was completely filled with drift and débris at the time the later structure was erected.

The inner dimensions of the room were: Along the north wall, following the curve of the kiva at this point, which formed the north wall of the room, 6 feet 7 inches. East wall, 5 feet 10 inches. South wall, as it stood, 6 feet 5 inches; but no doubt it originally extended to meet the kiva wall at the west, when its total length was 8 feet 11 inches. West wall, from the northwestern wall of the kiva to its end, 2 feet 2 inches; here the wall formed an angle by turning westward and becoming the northern side of what had been a door-like opening or passageway, 1 foot 7 inches wide, as shown on the plan. The northern end of the west wall had fallen. 
The maximum height of the walls of the room above its floor was 4 feet 10 inches, and there is little likelihood that this height was greatly exceeded when the room was occupied, if we may judge by the average height of the ceilings of the related houses of Hawikuh. The walls had not been plastered, and the floor was of ordinary earth. Access to the house seems to have been gained by means of a hatchway in the roof and by a ladder leading to the narrow passageway described. Not a trace of wood was found.

The inner or buttress wall of the kiva was exposed about nine inches above the floor of the little room, hence what has been referred to as the northwestern niche of the kiva was slightly below the floor level of the room and therefore was not utilized by its occupants. The top of the buttress wall, however, would have formed a convenient though narrow seat along the curved northern side of the domicile.

In removing the walls of the little structure, made necessary in order to expose the kiva floor, there were found, in the masonry mortar of the upper part of the east wall, some turkey leg-bones and also the gravelly contents of a gizzard. The Zuñi workmen could offer no explanation of this. Similar turkey remains were found immediately beneath the floor of the recent house in Kiva II, as will later be mentioned.

\section{KIVA II}

Practically adjoining Kiva I at the west was Kiva II, the distance between the inner face of the main walls of the two structures being only 5 feet 2 inches (pl. I, II, XI, xII). The intervening space was filled with earth and stones. The masonry was not of the superior character of that of Kiva I. As in the case of the latter, however, a relatively rude dwelling had been erected after the abandonment of the kiva, its walls built largely against the north and northwest arc of the ancient chamber by the people who first settled at the Hawikuh site. This more recent dwelling will be referred to later.

Masonry.-The average diameter of Kiva II (about 15 feet $3 \frac{1}{2}$ inches) was slightly less than the true diameter of Kiva I (17 feet). The circumference of the kiva varied somewhat from that 


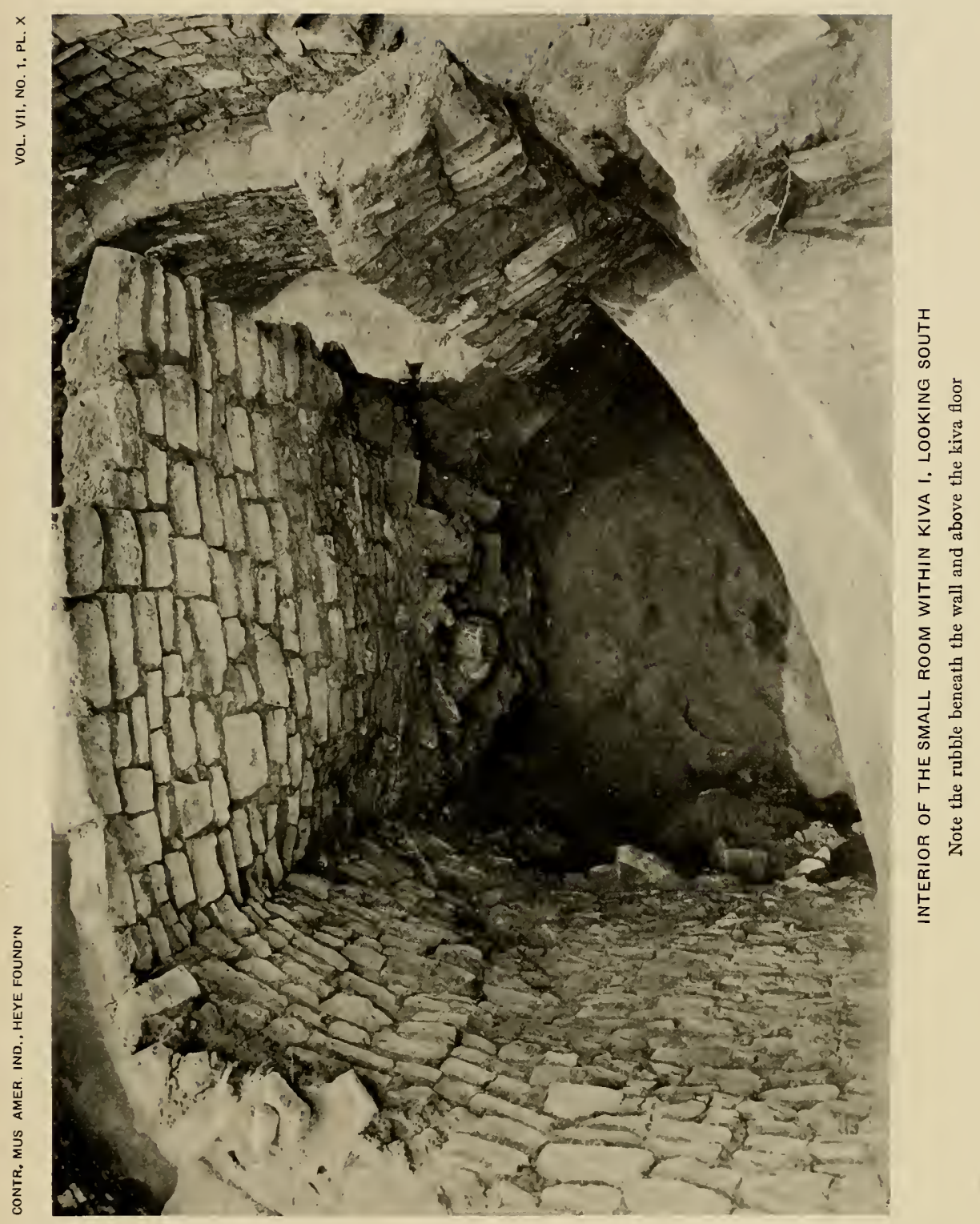




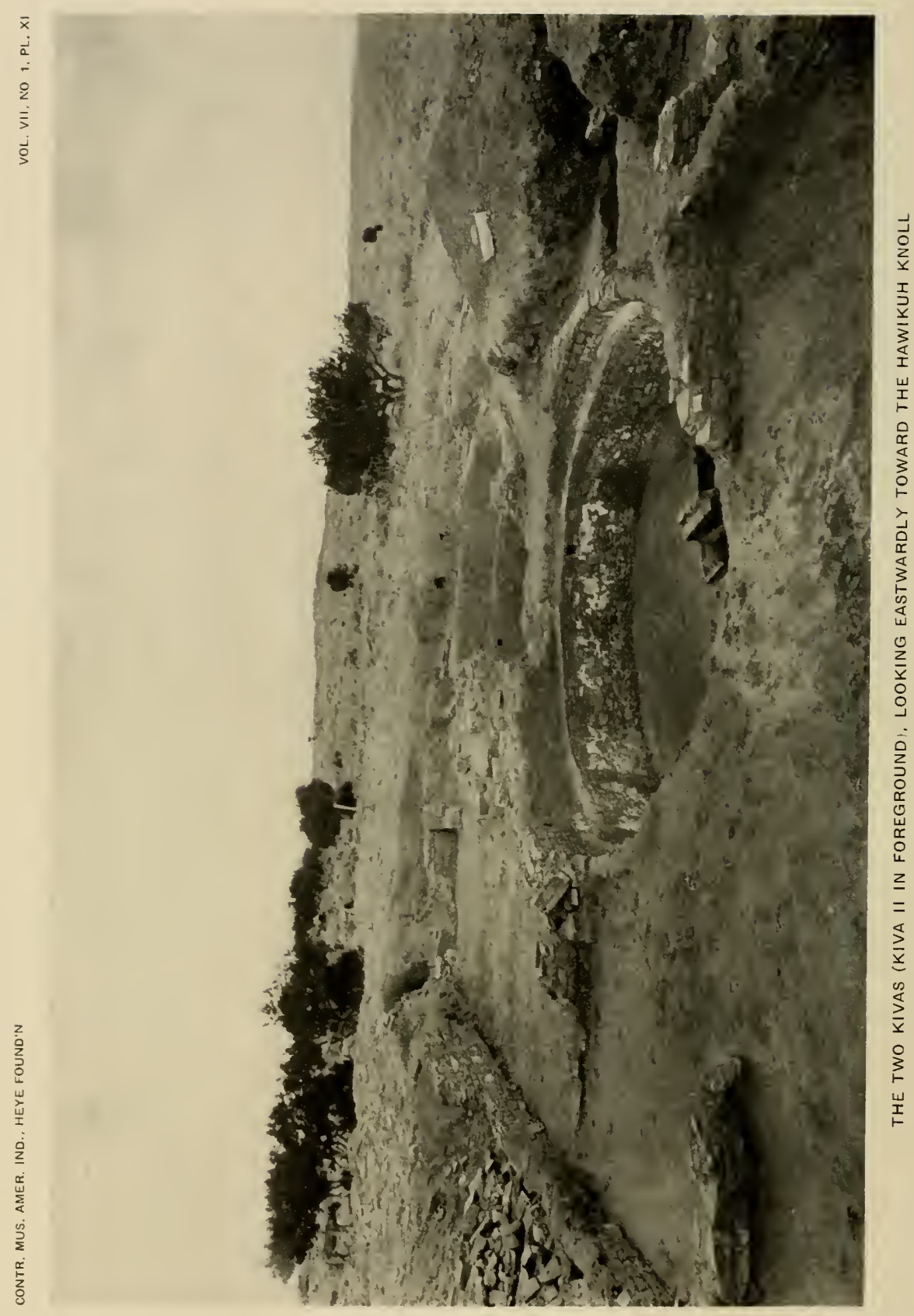


of a circle, for the diameters measured: N-S, 15 feet $4 \frac{1}{2}$ inches; E-W, 15 feet $2 \frac{1}{2}$ inches; NW-SE, 15 feet 7 inches, and NE-SW, 15 feet $\frac{1}{2}$ inch. But even with this disparity there is little likelihood that the ground-plan was the result of mere eye-work. The southern section of wall was somewhat flattened, possibly through weakening by the reconstruction of the air-duct which passed through the wall at this point; indeed the courses of masonry here dipped slightly downward toward the horizontal shaft through the wall, from a point seven feet east of the opening to another two feet west of it (pl. XII).

Further indicative of the relatively inferior quality of workmanship of Kiva II, it may be mentioned that at a point in the northeastern portion of the main wall ten courses of masonry, from the top of the inner buttress wall to the surface, were laid with unbroken joints. Yet even with such defects as those mentioned, the masonry of Kiva II was at least equal in quality to that of any of the dwellings of Hawikuh. As intimated, the structural features of the walls were the same as those of Kiva I. The buttress wall ranged in height from 2 feet $1 \frac{1}{2}$ inch to 3 feet, this maximum prevailing except for a space of about seven feet in the western portion, where it had either disintegrated or its upper stones had been carried away by the later comers. The maximum height of the main or outer wall above the kiva floor (at a point eastward from the northern niche) was 5 feet $4 \frac{1}{2}$ inches (or 1 foot $3 \frac{1}{2}$ inches lower than the maximum height of the remaining walls of Kiva I), the minimum (the eastern and western sections) 2 feet $1 \frac{1}{2}$ inch. The thickness of the main wall at the top was not readily determinable, because the outer facing stones had been almost entirely removed by the later Hawikuh builders; but exposure of a section of the wall where the ventilator shaft passed through it showed that here, at least, the entire wall was 1 foot 3 inches in width.

At this point should be recorded the fact that the top of the highest part of the wall of this kiva, above mentioned, was only a few inches lower than the foundation course of the long, welllaid wall extending $\mathrm{E}-\mathrm{W}$ north of the two kivas (see plan), and which had formed the northern side of the kiva compound to which 
reference will later be made. From this fact it may be assumed that the kiva was probably never much higher than the maximum height of the walls above given, in which case it rose only slightly above the surrounding level.

Wall Plaster.-As in Kiva I, the walls had been successively washed with thin plaster-five alternate coatings of adobe and gypsum. Considerable patches of plaster still adhered when the wall was uncovered, but much of it scaled off as soon as exposed to the dry air.

Floor.-The floor was chiefly of hard adobe, with the appearance of having been finished by tramping rather than by plastering, as it was more pitted than smooth. Its level was only $2 \frac{1}{2}$ inches lower than that of Kiva I.

Niches.-A.s in the other kiva, there were three niches in the buttress wall-in the north, the southeast, and the southwest, as indicated on the plan. These measured as follows: Northern, $5 \frac{1}{4}$ inches wide, 6 inches high, $7 \frac{1}{2}$ inches deep; 2 feet $\frac{1}{2}$ inch above floor. Southeastern, $4 \frac{3}{4}$ inches square, $4 \frac{3}{4}$ inches deep; 2 feet $4 \frac{1}{4}$ inches above floor. Southwestern, 4 inches wide, $3 \frac{1}{4}$ inches high, $3 \frac{1}{2}$ inches deep; 2 feet 3 inches above floor. The latter two niches were somewhat rounded by plastering. Possibly the placing of these niches, designed to be at the cardinal points, was influenced by the position of the sun at the time of year when the kiva was built. The northern niche was not in alignment with the fireplace and the ventilator opening, to be described; its sill, eastern jamb, and lintel were each of a single slab, and the lintel, while spanning the left jamb slightly, rested on the slab that formed the right jamb. The niche at the southwest was poorly constructed, as its lintel did not span either side.

Fireplace.-The fireplace bore the same relation to the other floor features as that of Kiva I. Its inside measurements were 1 foot 4 inches $\mathrm{N}$-S by 1 foot $11_{2}^{\frac{1}{2}}$ inches $\mathrm{E}-\mathrm{W}$, by $9 \frac{3}{4}$ inches deep. The stone sides averaged 2 inches in thickness and rose a couple of inches above the floor level. The fireplace was completely filled with ashes; its base was of sand. In the ashes was found an ancient gray bowl decorated in black (pl. xxiv, a). 


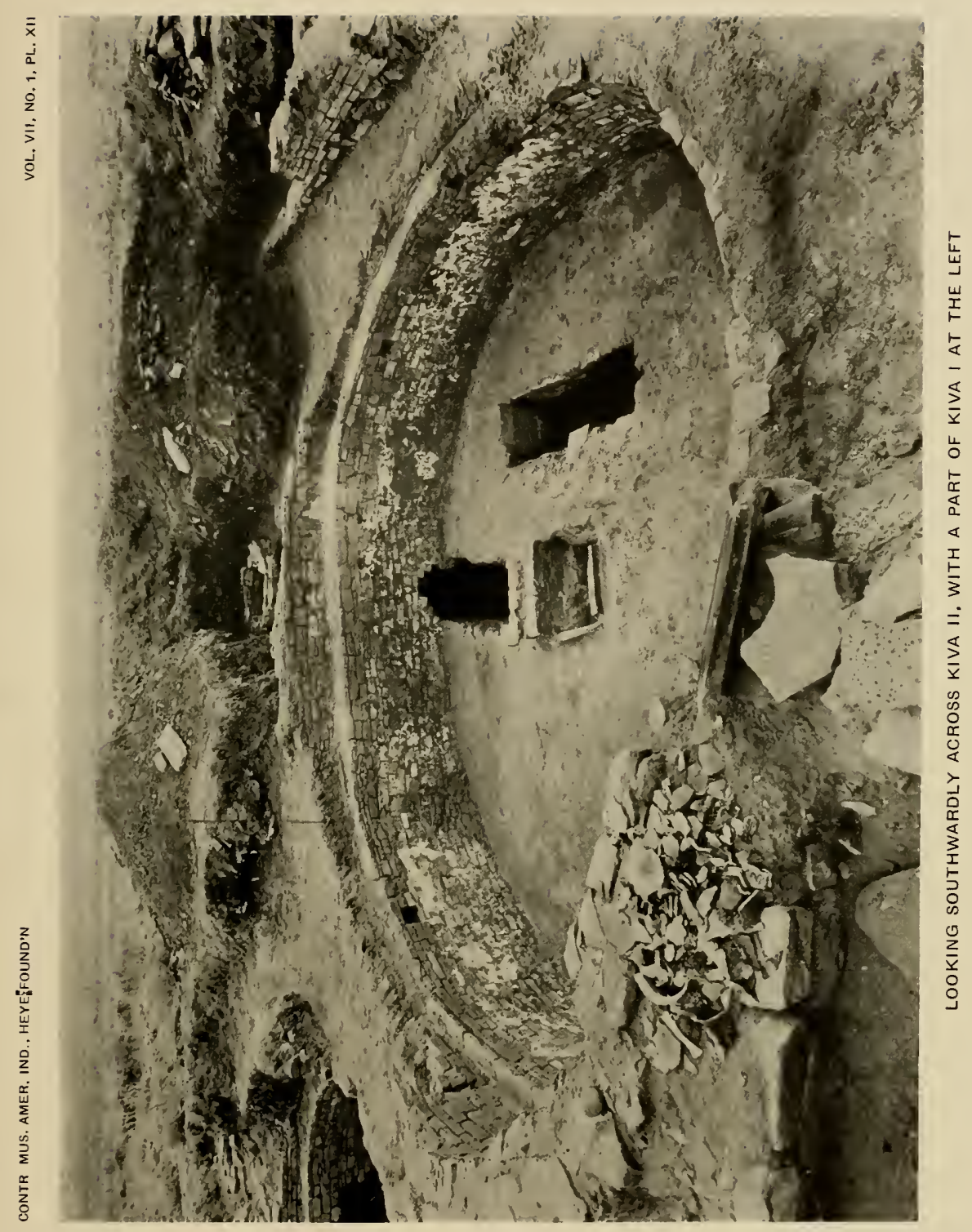




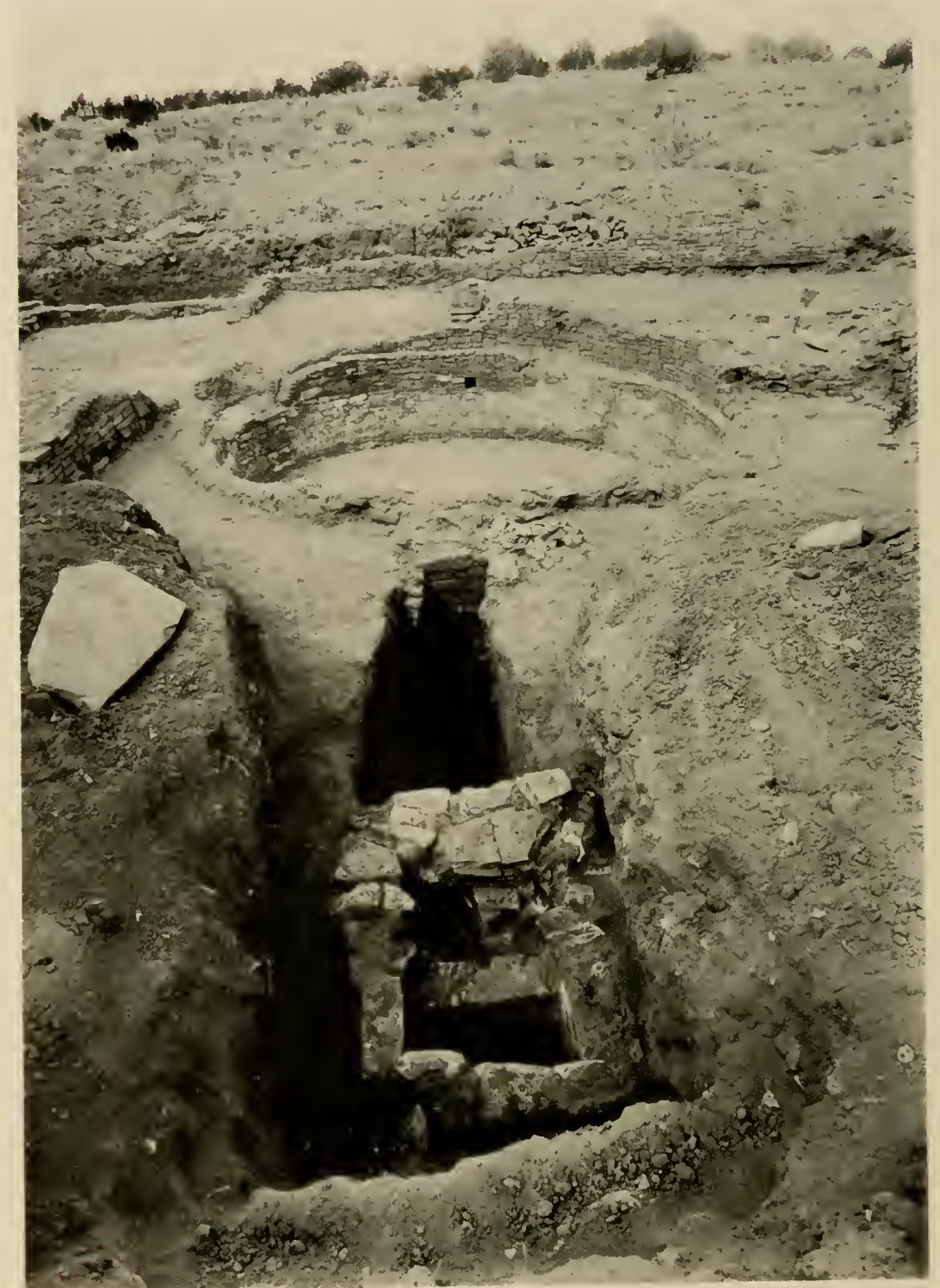

LOOKING NORTHWAROLY ACROSS KIVA II FROM ITS LATER VENTILATOR FLUE. THE OLDER FLUE IS SEEN JUST OUTSIDE THE KIVA WALL 
Fire-screen.-The fire-screen, or deflector, consisting of a neat low masonry wall two stones wide, formed the rear or southern side of the fire-pit; it was 2 feet $\frac{1}{2}$ inch long, 11 inches thick, and $7 \frac{1}{2}$ inches high.

Ventilator.-At a point $2 \frac{1}{2}$ inches to 4 inches south of the firescreen was the northern edge of the ventilator opening in the floor, which probably had measured 1 foot 2 inches to 1 foot 3 inches $\mathrm{N}$-S by 1 foot $4 \frac{1}{2}$ inches $\mathrm{E}-\mathrm{W}$, judging by some small stone slabs set at floor level at its eastern and western sides, and by the absence of sticks such as supported the slab covering of the horizontal shaft of the ventilator. This opening, not otherwise distinguishable from the shaft into which it merged, was, like the shaft itself, 2 feet $4 \frac{1}{2}$ inches in depth below the floor of the room, the floor thickness here consisting of five inches of hard adobe. The width of the opening of the ventilator at floor level was slightly less than that of the horizontal shaft, measured at the bottom, which was 1 foot 5 inches, because the slabs at the rim of the opening projected slightly over the ventilator walls.

Along the top of the uppermost course of masonry of the shaft or tunnel, and five inches below the surface of the kiva floor, sticks had been laid from side to side to support the covering. These sticks, some round, others flattened, ranged in thickness from threequarters of an inch to $2 \frac{1}{4}$ inches, placed 2 inches to 4 inches apart. Over these bark and smaller sticks and splinters (as if the refuse of a wood-pile) had been placed transversely, likewise, if we may judge by a single cast in adobe plaster found in the shaft (which, however, may have been intrusive), a coarse grass such as still grows abundantly in the swampy area of Ojo Caliente, about three miles away, and which the Zuñi call tópukawe, 'weak water weed.' Over this support the five inches of adobe mud had been deposited, as mentioned, bringing the covering to floor level.

The masonry about the shaft opening in the kiva wall, as well as that of the shaft itself, was of superior construction, the stones being closely laid in adobe mortar. Its walls bore no surface plastering, as it had of course been hidden from view; but its floor from the opening near the fireplace to the kiva wall was finished with very hard adobe. Incorporated horizontally in the west 
wall of the duct masonry were three large stones, their faces naturally smooth, extending from a foot within the kiva southward past its wall for a total length of 4 feet 5 inches. The length of the air-duct proper (measured from its point of junction with the opening in the kiva floor) to the outer face of the kiva wall was 4 feet 7 inches, while its total length was 16 feet $5 \frac{1}{2}$ inches. The horizontal shaft itself increased slightly in width toward the south, it being 1 foot 11 inches wide at the point where it reached the outer face of the kiva wall, and $6 \frac{1}{2}$ inches less at its junction with the floor opening behind the deflector.

There had once been a vertical shaft or flue immediately outside the kiva wall, but this evidently proving unserviceable, its walls were partly demolished and the horizontal duct extended southward 8 feet 11 inches, where it joined a new vertical shaft (pl. XI-XIV). In this reconstruction the entire south wall of the old vertical shaft was removed, and of course it became necessary to close the lower outlet and to roof the horizontal duct as far as the new vertical shaft. How the sealing of the lower outlet of the old vertical shaft was effected was not apparent, for while the ends of the stick supports, with the ends also of the superposed bark and splinter covering, were present in the western side, they were absent from its eastern wall, where a course of hard adobe mortar, 3 inches to 5 inches thick, took the place of a course of stones. In this adobe was embedded a misshapen stick extending lengthwise of the wall of the horizontal shaft, but the early collapse of the lower part of the masonry of the main wall of the kiva where it spanned the duct, here supported by cross-sticks, prevented determination of its function. However, that the duct was extended southward after the first flue was built is beyond question, for there was not only a break in the east wall of the horizontal shaft in line with what had been the south wall of the old vertical flue, but the floor of the shaft changed from adobe to earth at this point.

After following a horizontal line from the extreme northern end of the shaft to the outer face of the kiva wall, the cross-sticks that had supported the covering of the shaft took a new level, $2 \frac{1}{2}$ inches higher immediately outside the kiva wall, and, continuing practically level in the west wall of the shaft for a further distance of 




VENTILATOR SHAFT AND FLUE OF KIVA II, LOOKING SOUTH 


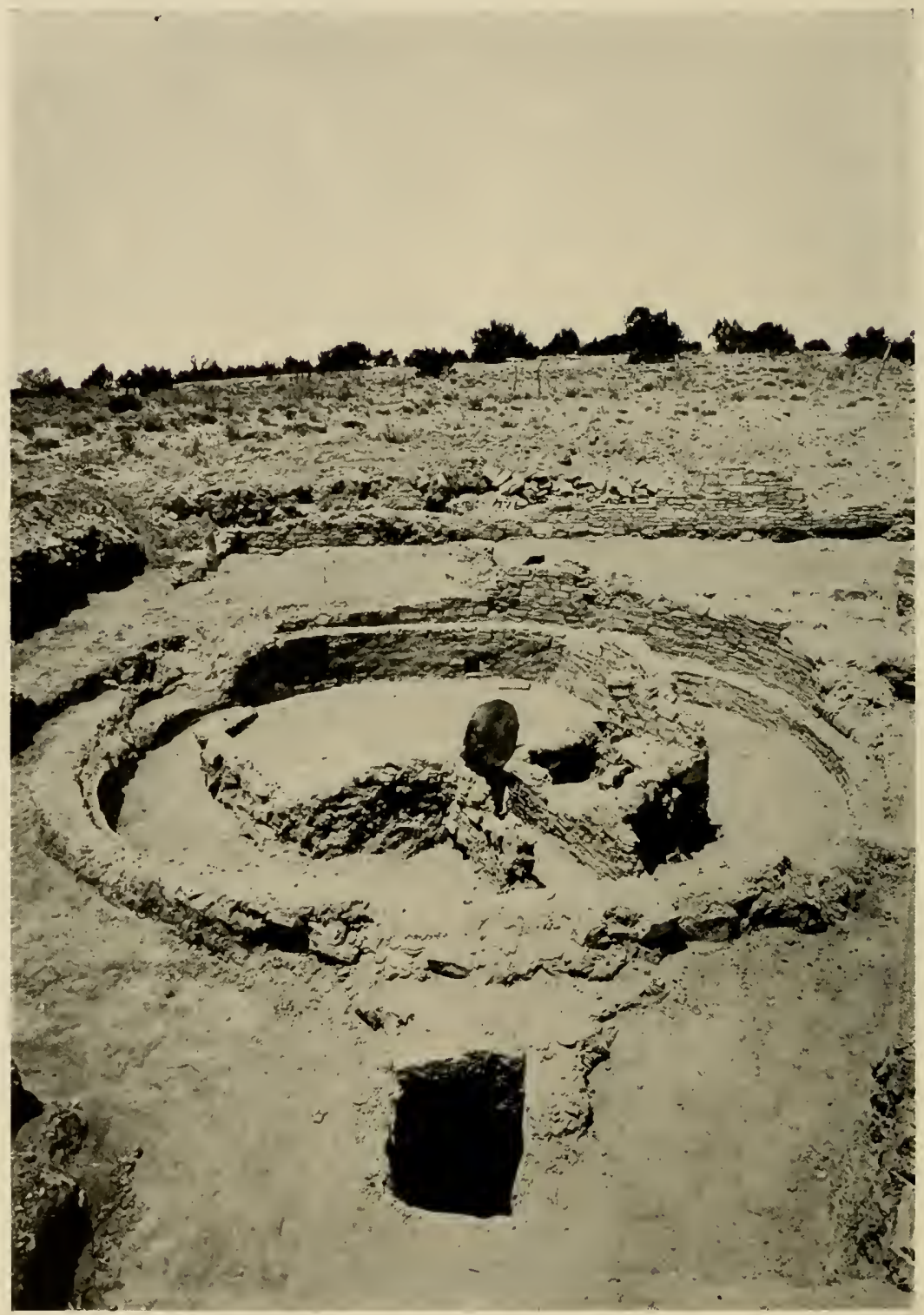

KIVA II BEFORE THE REMOVAL OF THE SMALL HOUSE BUILT WITHIN IT.ELOOKING NORTH. VENTILATOR FLUE IN FOREGROUND 
3 feet 6 inches, became "stepped," so that, at a point 7 feet 7 inches from the outer wall of the kiva, the cross-sticks had been a foot higher. This was due apparently to the necessity, in the minds of the builders, of making the shaft rise slightly in its southerly course in order to increase the draft, for the height of the west wall of the duct at its southern end was only 1 foot 9 inches, whereas at the point where it passed through the kiva wall it was three inches higher, the difference being due to the change in the floor level of the shaft. A similar condition prevailed with respect to the east wall of this shaft, except that, instead of being stepped, it rose gradually until it became practically level with the west wall at the same southerly point referred to. The floor here was not plastered with adobe like the northern or older part of the duct, as before mentioned. Near the southern end of the horizontal duct, 11 inches from the north wall of the later vertical shaft, a rude wall had been built, evidently to give the thin walls of the latter greater support (pl. xiv). This short wall had rested on the crosssticks of the horizontal shaft at this point, which, becoming decayed, caused the lower courses of the wall masonry to sink. The stonework of this rude wall was 1 foot 6 inches thick. The space between it and the north wall of the later shaft was filled with adobe.

At its upper or surface opening the later shaft measured 1 foot 2 inches to 1 foot 3 inches N-S by 1 foot $10 \frac{1}{2}$ inches E-W (pl. XIV). Its walls averaged 7 inches in thickness, except the northern one, which was $9 \frac{1}{2}$ inches. The total depth of the vertical shaft was 3 feet $\frac{1}{2}$ inch. In the southern face of the shaft, $10 \frac{1}{2}$ inches from its east side and the same distance below the top, was a rectangular opening, $4 \frac{1}{2}$ inches wide by 4 inches high (pl. xIv), indicating that at one time the top of this chimney-like vent rose above the surrounding surface. The purpose of this opening may have been to afford the necessary air during windy weather, such as often occurs in spring, when the prevailing winds from the southwest carry vast quantities of sand. It may have been found necessary during this season to close the larger opening with a slab of stone.

Vault.-A vault-like structure, similar to that in Kiva I, was in the floor; its width at the top was 1 foot $4 \frac{1}{2}$ inches to 1 foot 5 inches, the length 4 feet 9 inches, and depth 1 foot 1 inch. There was no 
masonry along its eastern end, and on the other sides the walls showed indication of hasty construction. Its floor was earthen. The distance from the southwest corner of the vault westward to the kiva wall was 1 foot 5 inches; southward it was 1 foot 10 inches, while its northwest corner was 3 feet from the western wall of the kiva. There was no indication that the vault had been covered, either by remains of supporting sticks or by the presence of stone slabs. Altogether the structure had an unfinished appearance.

Suggestive of the building of Kiva II at a period later than the other, and also that it was ancillary to Kiva I, is the fact that Kiva II was not provided with a shípapulima, a feature so common to ceremonial chambers throughout the Pueblo region. Possibly this second kiva was used largely as a gathering place and dormitory by the men, as was the custom at least in early historic times, and that the ceremonies were performed in Kiva I, which was provided with that essential adjunct to indoor religious rites, the shipapulima.

\section{Later Domicile}

As in the case of the other ceremonial chamber, Kiva II contained the remains of a domicile built by early Hawikuh villagers. The structure was as rude as that within Kiva I, although the same kind of material was available for its erection. It was larger than the other dwelling, however, and in outline was roughly circular (pl. xv, xvI).

The same method was employed in the erection of this building as in the other, namely, the kiva having been completely filled through long abandonment, an excavation covering the desired area, shape, and depth, was made, against the vertical cut of which the new walls were erected, excepting at the northern side, where the kiva wall was utilized. The masonry of only the exposed inner face of the house wall was laid with any degree of finish, the rear or outer face being against the excavation and therefore not exposed to view. The wall of this house was irregularly 5 inches to 11 inches in thickness. The floor of the domicile was 1 foot $10 \frac{1}{2}$ inches above the floor of the kiva.

The diameters of the room were: N-S, 9 feet 6 inches; E-W, 10 feet 2 inches; NW-SE, 10 feet 5 inches; NE-SW, 11 feet 7 inches. 


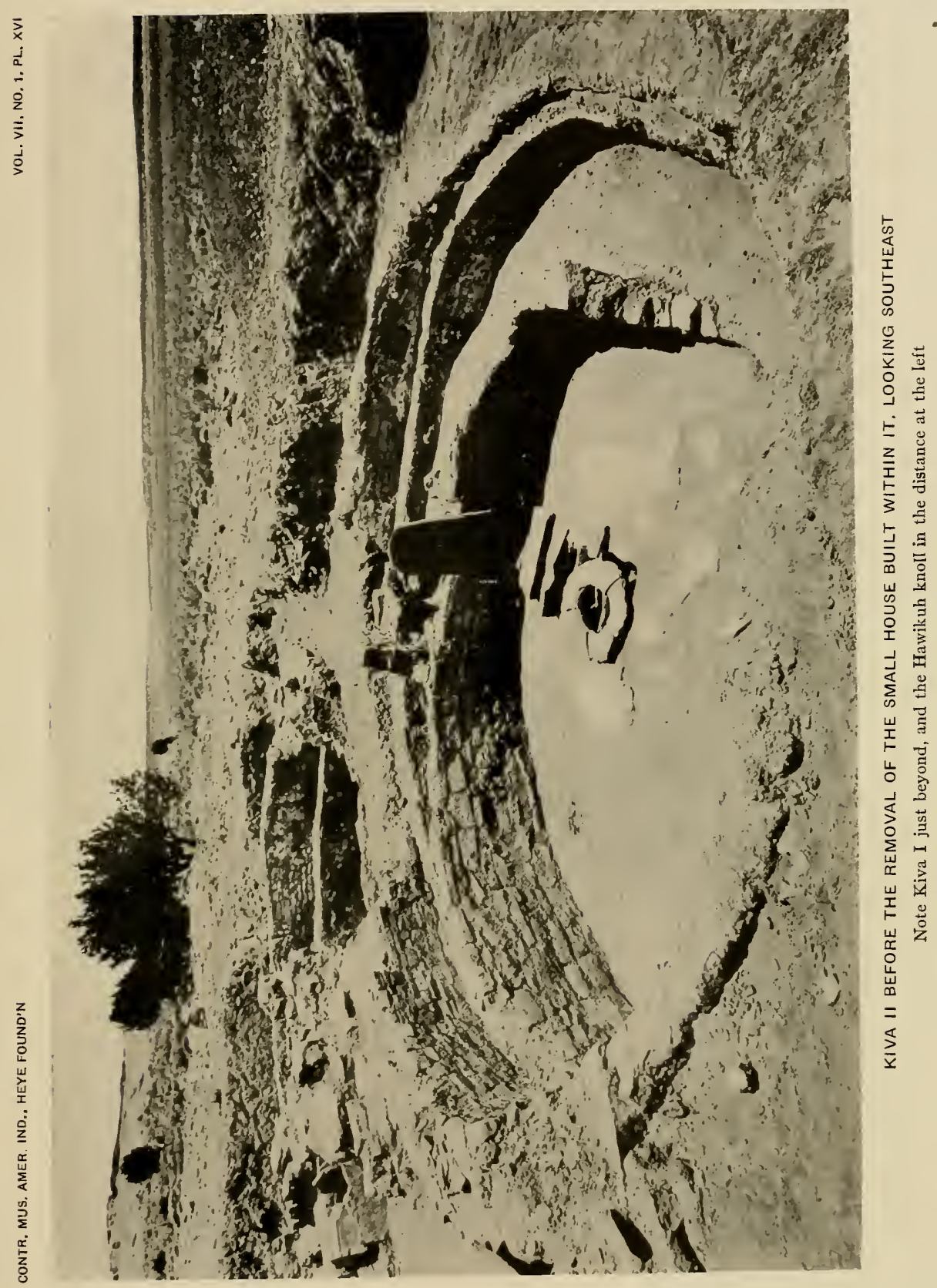




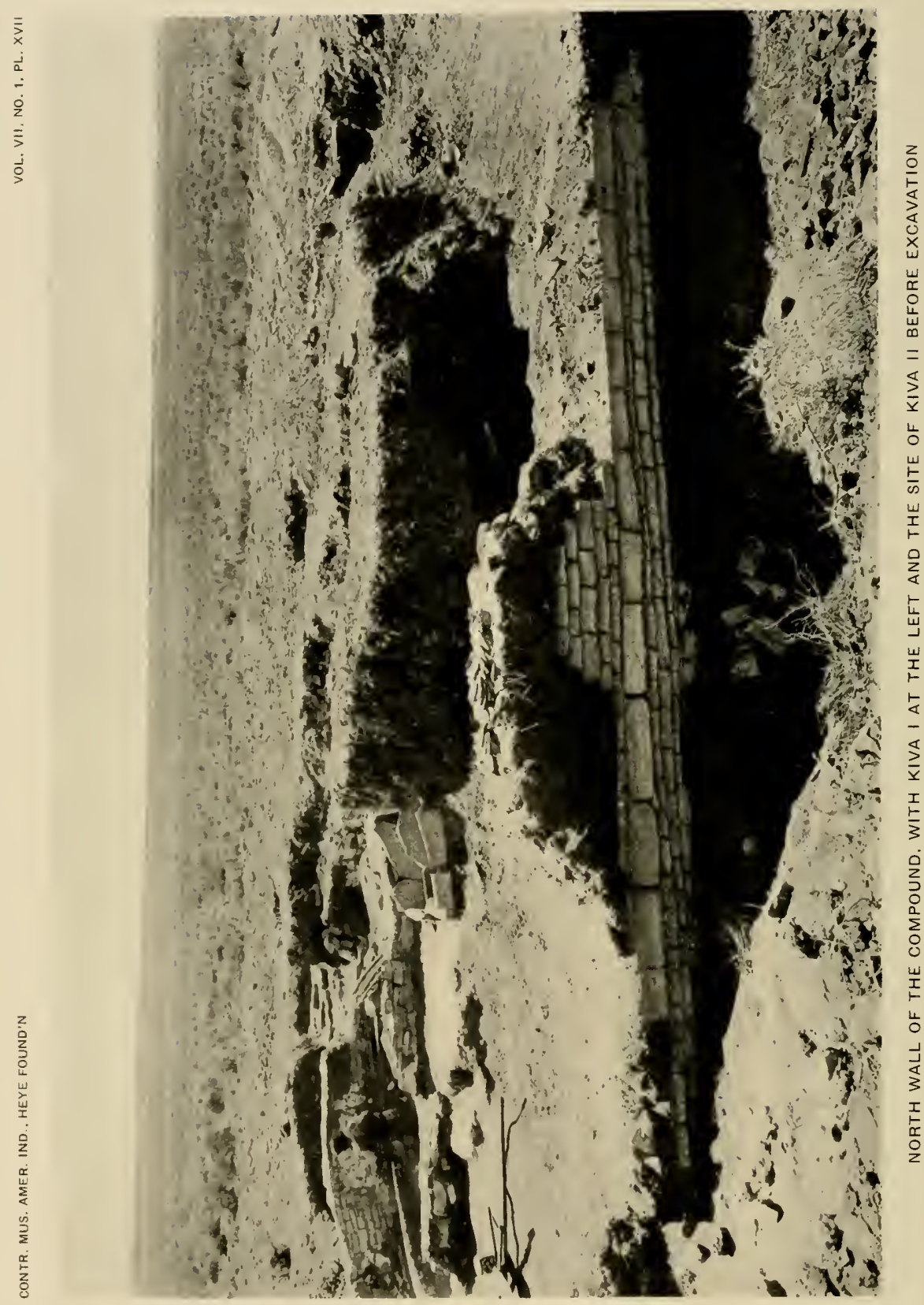


The northeastern point from which the measurement was made was 2 feet 5 inches east of the northern niche of the kiva, and was the point of contact of the wall of the domicile with the curving north wall of the kiva (pl. xv). Little of the west wall of the house was standing; indeed the northern end of this wall was entirely missing. Unlike the dwelling within Kiva I, the walls of that built within Kiva II had been thinly plastered.

In the southern arc of the room there was what appeared to have been a doorway, 1 foot 2 inches wide, with jambs formed of slabs set on end in such manner as to make a slight recess or jog in the wall, designed to support a door-close of stone, 2 feet 10 inches high, 1 foot $1 \frac{1}{2}$ inch wide at the bottom, and $1 \frac{3}{4}$ inch thick. This slab had fallen to the floor, but is shown in approximate position in the illustrations. The opening entered a passageway, 4 feet 3 inches long to the end of its broken walls, and of the same width as the doorway, from which a ladder possibly arose to the roof, otherwise entrance and exit were gained by means of a hatchway and a ladder about the middle of the dwelling, and the narrow passage was used for some other purpose, possibly as a ventilator, which seems less likely. So little of the structure remained that it was not possible to determine the true purpose of such a narrow passage, and the question became more involved by the existence of a strange structure east of it. This contrivance consisted of a block of masonry, measuring outside 2 feet 9 inches $\mathrm{E}-\mathrm{W}$ by 3 feet 7 inches $\mathrm{N}-\mathrm{S}$, by 1 foot 3 inches high, and hollow in the middle. At the height given, the top seems once to have been, judging by a horizontal slab still in place; yet above this, on the eastern side, rose a masonry wall, 12 inches high and only 4 inches to $4 \frac{1}{2}$ inches in thickness, making the feature still more problematical (pl. xv).

There were two fireplaces directly in front of the doorway, the smaller of which, 1 foot 8 inches from the south wall of the room, measured (inside) 9 inches N-S by $11 \frac{1}{2}$ inches $\mathrm{E}-\mathrm{WW}$, by 3 inches deep to its base; but the stone forming its north side rose $3 \frac{1}{2}$ inches and that at its south side 5 inches above the floor of the room. The north stone was rounded at the top and was approximately 4 inches thick, while the south stone, irregular at the top, 
as if accidentally broken, was only $1 \frac{1}{2}$ inch in thickness. The other side stones reached floor level.

The north slab described formed the south side of the adjoining larger fireplace, the dimensions of which were 1 foot 3 inches N-S by 1 foot 8 inches $E-W$, by 1 foot 2 inches to its earthen base in which was embedded a single small stone. All the sides except the southern were flush with the floor of the room. The east and west sides were formed of stone slabs. The fireplace was wellfilled with ashes, in and above which were the several pieces of an annular stone that doubtless had served as a pot support. A similar one, with the fragments of a cooking-pot beneath, was found in place in one of the earlier dwellings of Hawikuh. Stones of the same general kind, usually well pecked to shape, were rather numerous in the débris of Hawikuh houses, but were never found in place, as they had formed the frames of hatchways in the roofs, which must have collapsed soon after the abandonment of the pueblo. The Zuñi employed the same kind of device until recent years. The photograph (pl. XvI) shows the pot support as it may have been when in use over the fireplace.

Various irregular flagstones were embedded in the floor about the fireplaces, and indeed similar stones covered much of the western half of the room, while a row of smaller ones had been laid against the north wall, among which was part of a hatchway frame with a mano laid within its. curve, while another mano adjoined it (pl. I). Only a couple of inches above the latter mano, in the wall, was the northern niche of the kiva (pl. xv). With the exception of the paved spaces described, the floor was earthen.

Immediately beneath the floor of the domicile, against the north wall of the kiva, were some turkey-bones and the small gravelly contents of a gizzard, offering a reminder of similar remains found in the wall masonry of the little domicile built within Kiva I. In close proximity was a diminutive jar decorated in black glaze on red (pl. xxix, $d$ ), typical of the pottery of Hawikuh rather than that of the ancient kiva. So highly regarded was the turkey by the Zuni that a skeleton of this bird was found in the cemetery of Hawikuh, accompanied with an earthenware food vessel, the remains having been deposited in much the same manner as the 


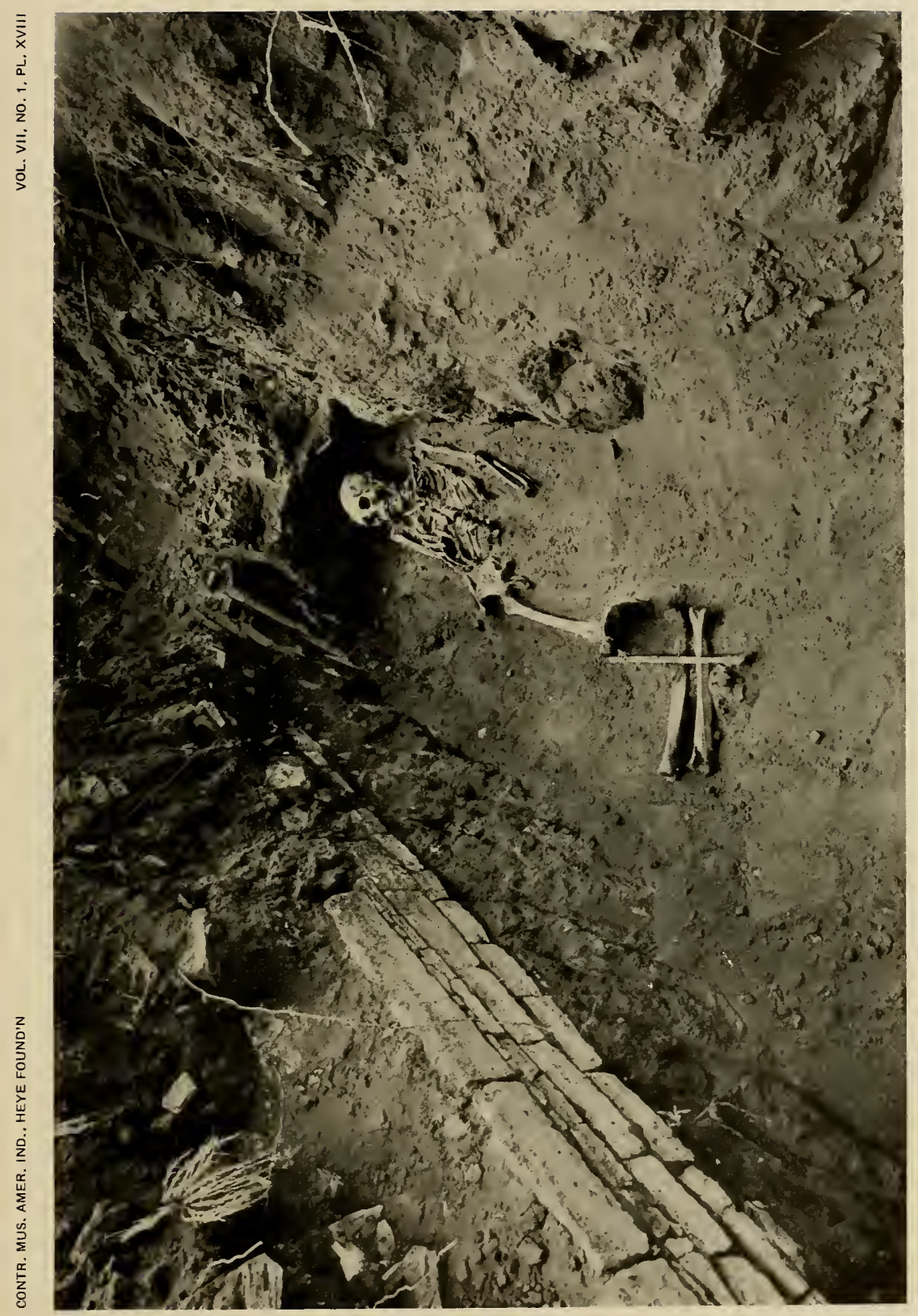

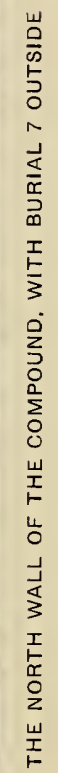




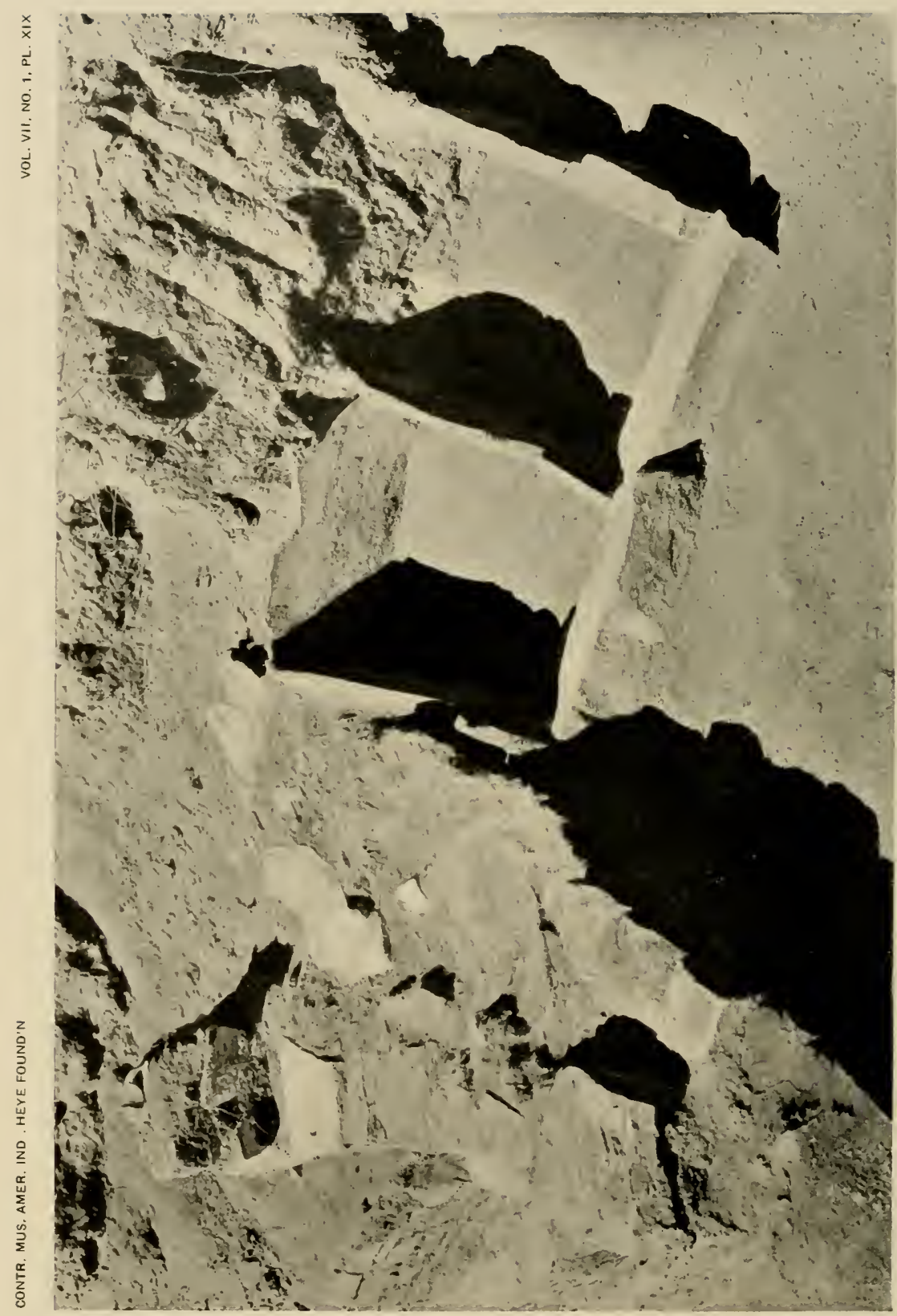

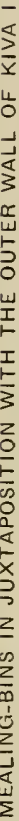


human interments surrounding it. Further allusion to this and to the use of turkeys by the Zuñi in early times will be made in the final report on the Hawikuh excavations.

\section{WALL OF THE KIVA COMPOUND}

The kivas had at least been partly enclosed by a rectangular wall (see plan), of the same excellent construction as the kivas themselves. Considerable parts of this wall, however, had been removed, no doubt by the builders of the two later dwellings within the kivas, as before noted, leaving nothing to indicate its original height. The highest part of the wall of the compound was at the north (pl. II, XVII, XVIII), where a section of nine courses of masonry was still intact. Only a glance is sufficient to show the painstaking manner in which the stones were laid, especially in the outer face of the wall. Only small portions of the east and west walls of the compound remained (pl. II, xI), while the south wall, if such ever existed, had disappeared entirely, as transverse trenches failed to reveal it. Indeed the conditions seemed to indicate that the south side of the compound was open.

Fragments of walls extending inward here and there from the compound wall, as shown on the plan, indicated the former existence of living-rooms within this court, and this seemed the more likely by the presence of a pair of mealing-bins at the floor of the compound, near the northwestern arc of Kiva I, as shown in pl. II and xix.

\section{ARTIFACTS}

Of considerable importance to the question of the relative age of the two kivas and of the structures built within them is the pottery found during the excavation. Of course it was to have been expected that, with the disturbance of the fill caused by excavation to a sufficient depth by the later builders to afford space for the two dwellings described, more or less mixture of ancient and late potsherds would be encountered; but no recent sherds were to be expected below the level of the two houses, in the undisturbed débris and earth that filled the kivas. Such proved to be the case. 
Within both the domiciles pottery wholly typical of Hawikuh were unearthed, mixed with which were stray fragments of ware of the period of the kivas. Beneath the level of the houses, however, and throughout the parts of the kiva fill that had been undisturbed by the later comers, only the most ancient pottery of the region was present.

For a better understanding of the earthenware made by the people of this vicinity, prehistoric and recent, it may be mentioned that the earliest forms of decoration are the black-on-gray and the black-on-red, the latter often with a white and sometimes a yellow geometric pattern outside the bowls. Black-on-gray predominated. Synchronous with these were an excellent corrugated ware, sometimes worked into geometric patterns by pressing the clay, while plastic, with the finger or fingernail, a bone awl, a pointed stick, or other device. The varieties of painted pottery mentioned were unknown to Hawikuh except in the form of stray sherds (such as may have been gathered to be ground for use in pottery tempering), or an occasional entire vessel that may have been dug up and put to secondary use. Such painted vessels are characteristic of certain ancient sites about Hawikuh, as before mentioned, and with the corrugated ware they represent the only pottery known to the builders of the circular kivas.

The earliest pottery made by the Hawikuh dwellers is rather similar to the black-on-red already mentioned, but the decoration is in black or green glaze (the green ranging in tone from light to very dark), and usually with the white geometrical pattern beneath the outer rim. Corrugated ware was also manufactured, but it is crude in comparison with the excellent product of the same class made in pre-Hawikuh times.

Gradually the Hawikuh potters abandoned the glazed black or green on red or orange-red, and covered both bowls and jars with a white or creamy slip, on which were applied patterns in green, purplish, or black glaze, and usually also other colors in non-glaze. Ultimately the glaze, and likewise the white slip, disappeared, and there came into vogue a purely polychrome mat decoration, the colors varying greatly, and zoömorphic patterns, especially highly conventionalized avian designs and a few human and 



FRAGMENTS OF VESSELS OF BLACK-ON-GRAY WARE

(In the case of $g$, the black has burned to reddish-brown. Width of $b, 7$ in.; length of $e, 3 \frac{1}{2}$ in.) 

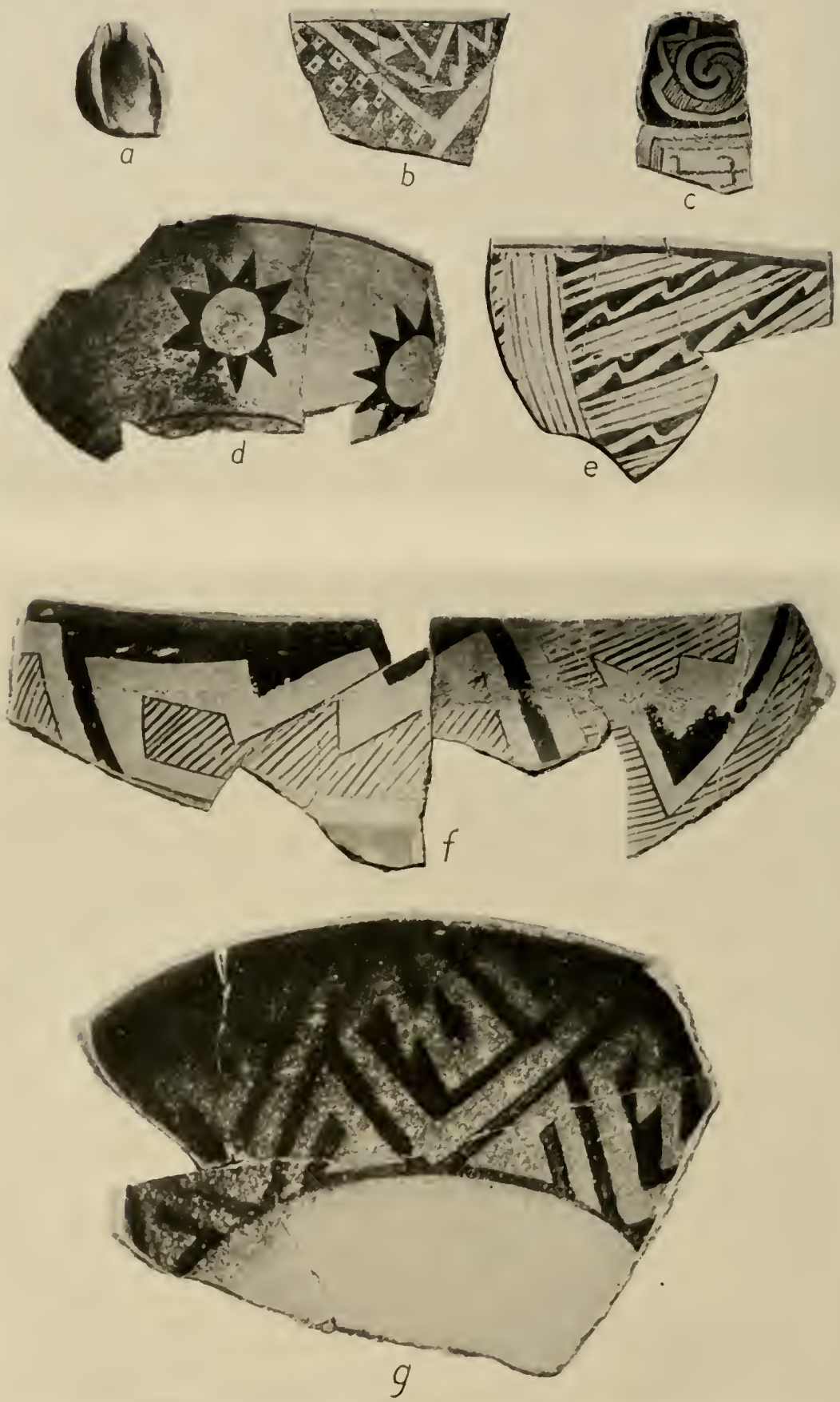

FRAGMENTS OF VESSELS OF BLACK-ON-GRAY (a-e) AND OF BLACK-ON-RED $(f, g)$ WARE

(Length of $d, 7 \frac{7}{3}$ in.; of $f, 10 \frac{1}{d}$ in.) 

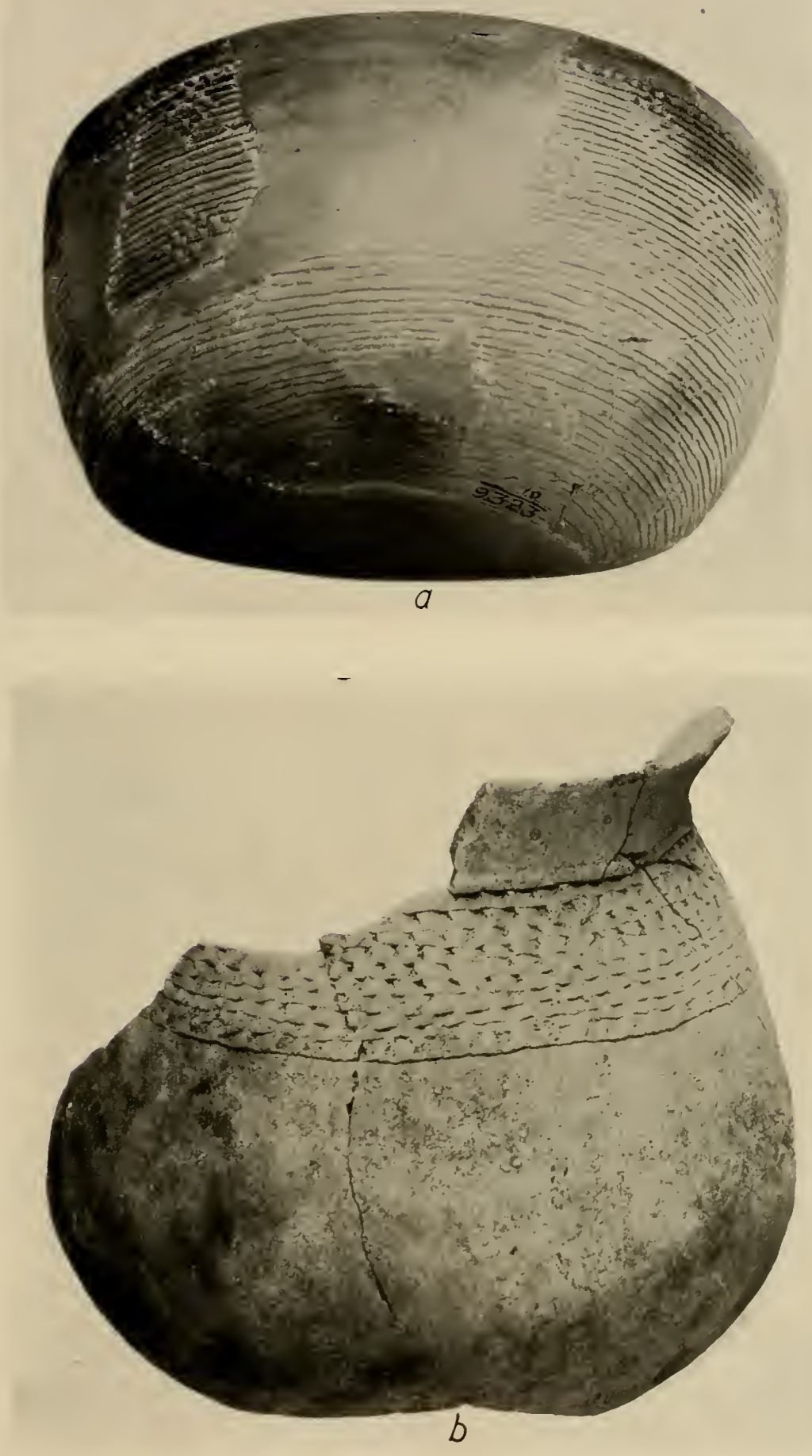

DEEP CORRUGATED BOWL OF THE FINER CLASS (a) AND PART OF A JAR WITH CORRUGATED BAND $(b)$

(Width of $a, 8 \frac{3}{b}$ in.; heig't of $b, 73$ in.) 

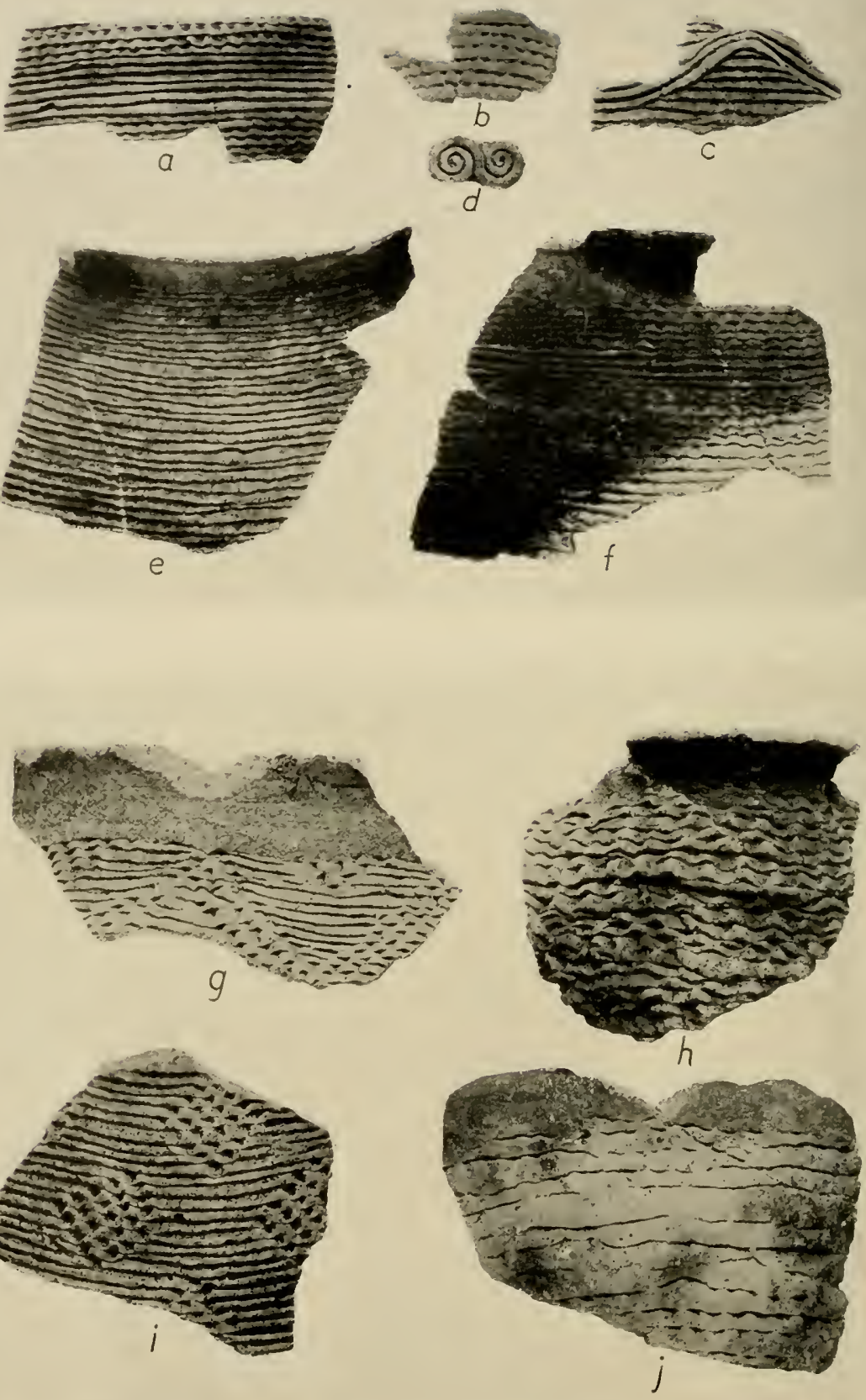

FRAGMENTS OF VESSELS OF CORRUGATED WARE

(Width of $f, 7$ in.; of $j, 5 \frac{1}{6}$.) 
masked figures, becoming the favorite motives of ornamentation. This polychrome ware had a wide range of form and decoration, and evidently covered a long period of time. It was still in use when Hawikuh was abandoned in 1670. Meanwhile, however, glaze decoration reappeared, but the glaze, often used in conjunction with flat pigments, was much more crudely applied than in early times. There were two general styles of this recent glaze pottery-that combined with the polychrome, and probably a somewhat later style consisting of hard thin ware covered with a rich dark-red slip, on which the glaze, usually black, was applied, generally in geometric patterns. The difference between this glazed ornamentation and that of the earliest glazed pottery of Hawikuh is generally apparent at a glance. The later glazed ware, as well as the later polychrome, was found in abundance in graves and rooms that contained also objects of Spanish introduction.

To summarize for our present purpose, the pottery found at Hawikuh and in its vicinity consists of the following general period types:

A. Black-on-gray; black-on-red; finely corrugated. Pre-Hawikuh period. Pl. xx-Xxvi, xxvirI.

B. Black or green glaze on red or orange-red. Corrugated much cruder. Earliest Hawikuh (prehistoric). Pl. xxII, $b$; xxıII, $h, i$; xxvi, $b$.

C. Black, green, or purplish glaze on white or creamy slip. Early Hawikuh (prehistoric). Pl. xxvin, $c$.

D. Black or green glaze on white or cream, with non-glaze colors introduced. This was the first step toward a pure mat polychrome. Prehistoric.

E. Polychrome. Various colors were used and life-forms became much more common. The glaze decoration had disappeared. The range of decorative designs indicates two periods, one merging into the other, the first prehistoric, the second prehistoric but extending into the historic period. Pl. XxviII, $a, b ; \operatorname{xxIx}, b, c$.

F. Recent glaze. The glaze, especially black, and green of varying shades, was revived, but the glaze was crudely applied. This style of ornamentation seems to have been gradually superseding the polychrome when Hawikuh was abandoned. PI. Xxix, $a, d$. (Present Zuñi potters deny all knowledge of the method of producing the glaze.) 
With this brief classification it may be said that the pottery from the kivas was exclusively of Type A, the bowl found amongst the ashes in the fireplace of Kiva II (pl. xxiv, a) being black-on-gray. Some of the sherds of corrugated earthenware exhibited fine execution.

On the other hand, the earthenware from the two rooms built within the kivas, or found as accompaniments of the adjacent graves, ranged in types from $\mathrm{B}$ to $\mathrm{F}$, the occurrence in the dwelling within Kiva I of a bowl of the last type (pl. xxIx, a), and of a scoop or dipper ground from a sherd of a large bowl also showing recent glaze ornamentation ( $\mathrm{pl}$. xxx), indicating that this dwelling, at least, had been occupied at two different periods. That pottery of this type $(\mathrm{F})$ was in general use after the coming of the Spaniards in 1540, and especially after the settlement of Franciscan missionaries at Hawikuh in 1629, there is no question. The tiny jar (pl. XxIx, $d$ ) accompanying the turkey burial immediately beneath the floor of the house built in Kiva II belongs to the same recent class.

Of the vessels or parts of vessels of a miscellaneous character found in the undisturbed fill of the kivas, those illustrated in pl. xx-xxII ; xxIv, $a$; xxv; xxvI; xxviII, $d$, are typical.

Of unusual interest is a small brownish-red jar, black within, in the side of which a large opening had been cut or broken and the edge smoothed by rubbing. There was nothing in association to indicate the use to which such a vessel could have been put (pl. xxvir, c). It was found in one of the recent domiciles.

To discuss the relationship of the pottery of the two kivas, and of Hawikuh itself, with that of other localities would carry us too far afield at the present time, and would anticipate a discussion of this interesting if complicated subject to be undertaken in presenting the final report on the Hawikuh investigations. Black-ongray and black-on-red earthenware vessels are common to many localities of the ancient Pueblo area of the Southwest; but the true Hawikuh type of pottery is of more limited range, yet it exhibits influence from several localities, no doubt due to the settlement among the Zuñi at Hawikuh of bands from other sections-from the Rio Grande, the Colorado Chiquito, and the Gila, at least, which brought with them their own art of pottery making and decoration. 

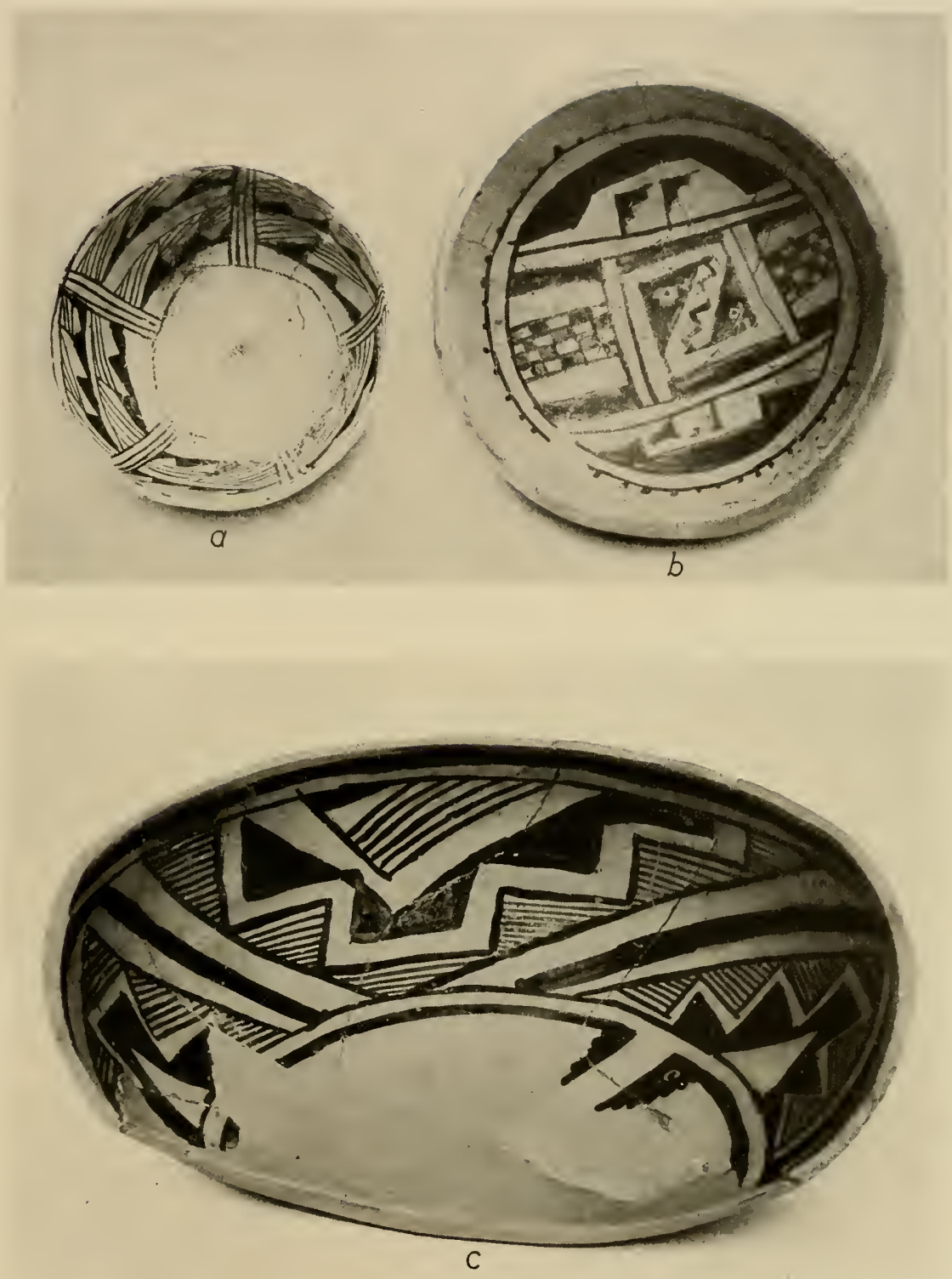

DEEP BOWL OF BLACK-ON-GRAY (a); BOWL OF FADED GREENISH GLAZE ON CREAM $(b)$; FRAGMENT OF BOWL WITH BLACK GLAZE ON RED (c)

(Diameter of $b, 10 \frac{1}{\text { in.; }}$ of $c, 10 ?$ in.) 


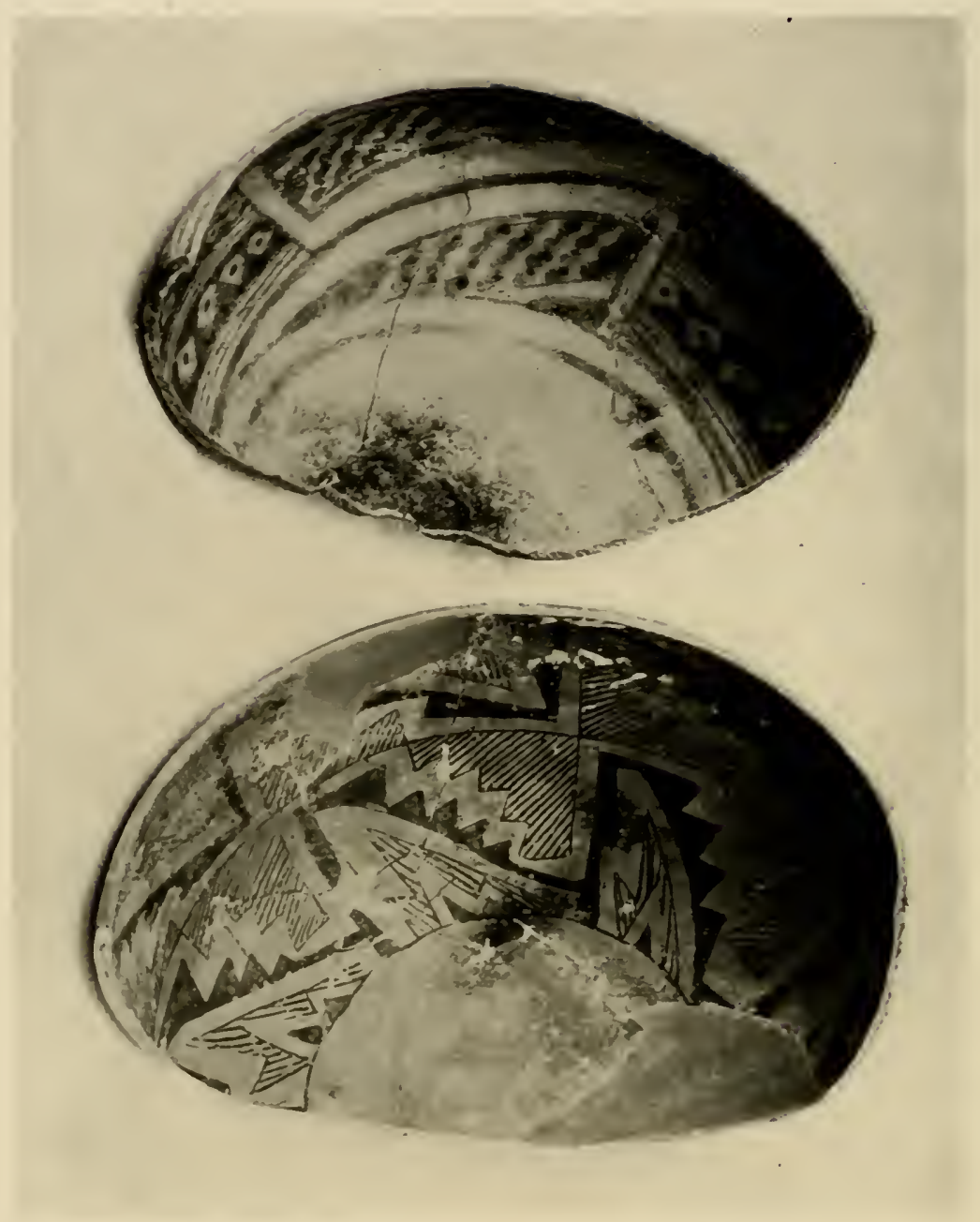

PARTS OF BOWLS WITH BLACK-ON-RED DECORATION

(Diameter of the lower bowl, 11 in.) 
The remaining artifacts found within the kiva compound, dissociated from graves, are insignificant, if we except a white stone pendant neatly fashioned in the form of a human foot (fig. 1), a neat shaft-smoother (fig. 2), the burnt deer-bone carved at the end in representation of a grotesque head, exhibited in fig. 3 , and a metate of unusual form, for, instead of being slightly concave in its entire upper surface, like the metates common to Hawikuh, it had raised longitudinal edges. All the other objects, chiefly of

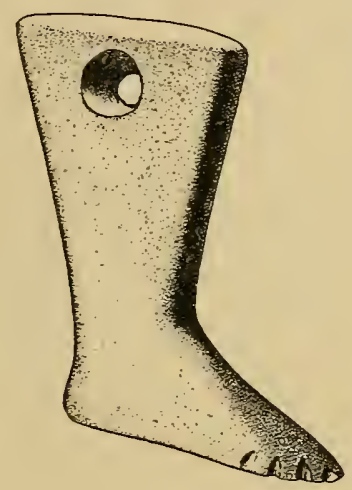

FIG. 1.-Pendant of white stone in the form of a human foot. $\left(\frac{1}{1}\right)$

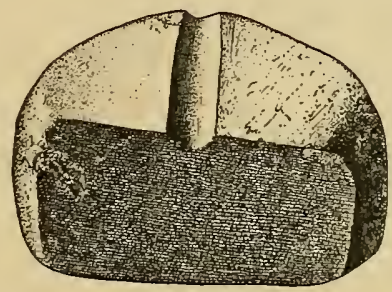

FIG. 2.-Shaft-smoother. ( $\left(\frac{1}{1}\right)$

bone (especially awls) and stone (mauls, metates, manos, and minor objects), were of such a commonplace nature that they require no specific reference.

\section{BURIALS}

Confirmatory of our conclusions respecting the sequence of the types of earthenware in the kivas and in the small dwellings within them, was the character of the pottery accompanying some of the ten burials unearthed just beyond the kiva walls (pl. I), the first of which led to the discovery of the kiva compound.

With Burial 1 were a small red jar of the Gila valley type, painted outside in black and white (pl. xxix, $c$ ), the black having become almost a smoky blue; a large bowl (pl. xxviIr, a) painted only on the exterior, below the rim, in black and white; a canteen (pl. XxvIII, c) with purplish glaze on a white slip. 
With Burial 3 was a bowl (pl. xxIv, $b$ ) decorated inside with green glaze on cream, and outside with sprawling crosses in the sametone (Type $\mathrm{C}$ ). The glaze was very dull.

Accompanying Burial 4 were a plain brown-ware cup (pl. xxvII, $d$ ) and a duck-shape receptacle (pl. xxvir, $a$ ), the period of which is determinable only by association, for vessels of the latter form are found among the earliest as well as among recent Pueblo remains.

In association with Burial 6 were a bowl of dull cream decorated outside with a simple geometric pattern in light red (Type E) of the earlier period (pl. xxvin, $b$ ), together with a duck-shape vessel (pl. xxvII, $b$ ).

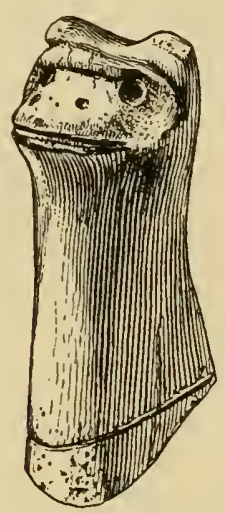

FIG. 3.-Burnt deer-bone carved to represent a grotesque head. $\left(\begin{array}{l}1 \\ 1\end{array}\right)$

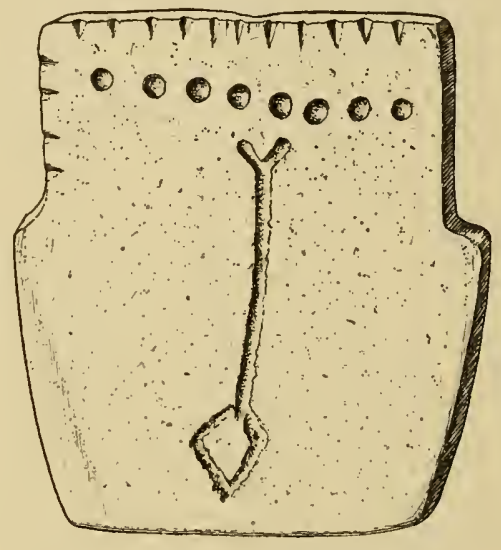

FIG. 4.-Incised ornament of white stone. $\left(\frac{1}{1}\right)$

With Skeleton 10 were various miscellaneous sherds, the oldest of which was a fragment of a bowl decorated inside with black on red and outside with crude geometric figures in mat white on reddish (Type A); this evidently was a stray fragment. There were also some early polychrome sherds.

It cannot be said whether these burials were made by dwellers at Hawikuh proper or by those who occupied the little houses within the kivas, as there was nothing in their remains to distinguish them. It is certain, however, that the dead were not of the people who built and used the two kivas, for the reasons stated, and also owing to the fact that some of the burials were no deeper 


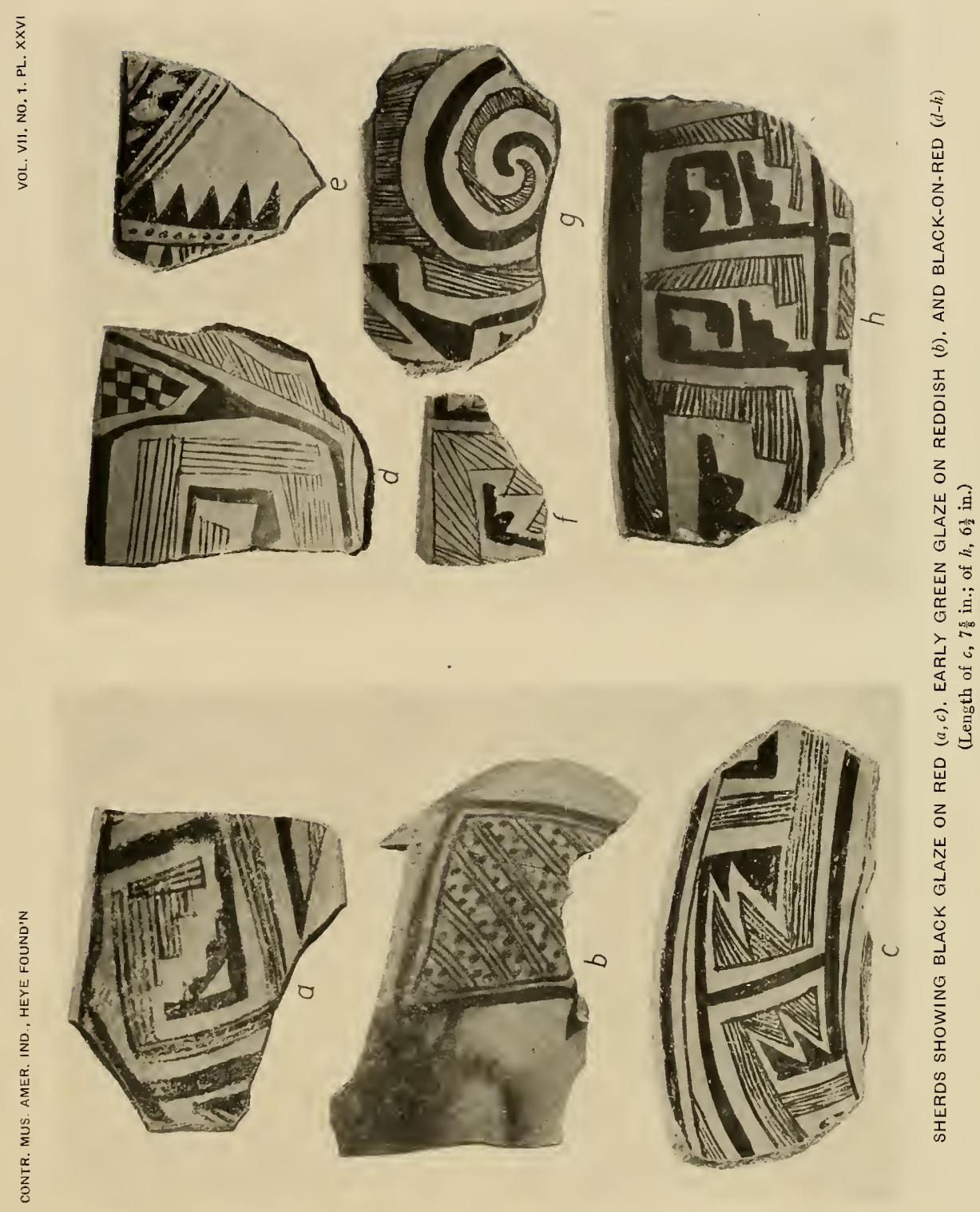



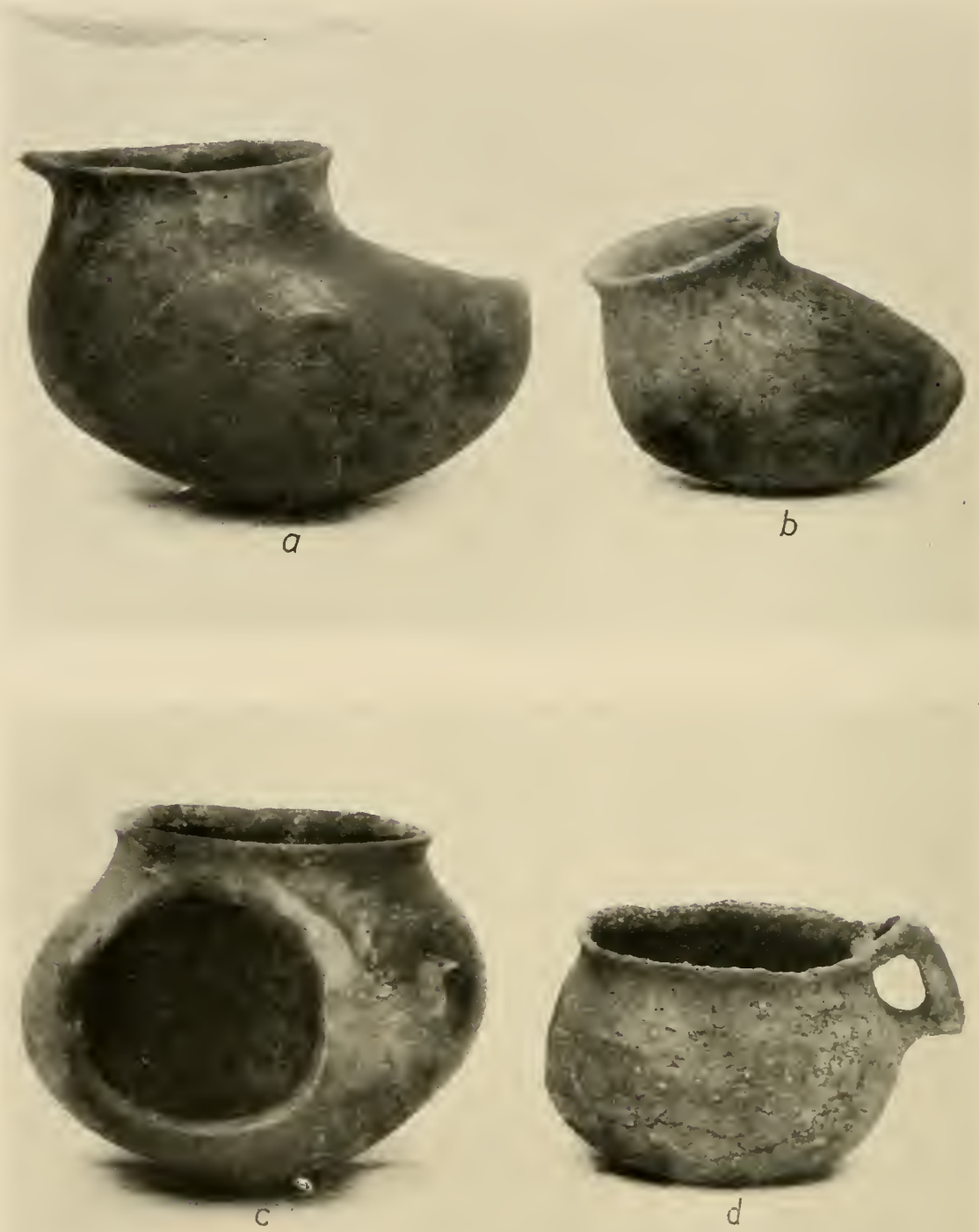

TWO BIRD-SHLPE VESSELS $(x, l)$, A CRUDE JAR WITH OPENING GROUND IN S:DE (c), AND A CRUDE CUP $(d)$. NONE OF THESE IS ORNAMENTED BY PAINTING (Length of $a ; 8 \frac{3}{4}$ in.; height of $c, 41$ in.) 
than the earthen floor of the compound, while one skull, indeed (Burial 5), rested on the top of the remaining wall of Kiva I.

It is rather significant that at Hawikuh the later burials were almost invariably headed eastwardly, while the ancient ones were as uniformly directed either northwardly or southwardly. Of the ten burials (all adults) near the kivas, six were headed south, one north, one northeast, and two west. The depth of the burials was $2 \frac{1}{2}$ to 4 feet below the surface.

In addition to the pottery mentioned in association with Burial 1 , there was a carved and incised white stone (akohakwa, 'white shell-bead stone') ornament, illustrated in fig. 4.

On the wrist of Skeleton 2 was a bracelet of olivella beads.

On the lower leg bones of Skeleton 5 was a rude stone pestle; at the left ear a plain white stone pendant; a bone awl was found at the right elbow, pointed toward the skull.

The only accompaniment of Skeleton 7 (pl. xviII) was an arrowpoint beneath the skull. This burial lay 1 foot 6 inches outside of and parallel with the northern wall of the compound.

With the exception of the pottery already noted, the other burials were without artifacts.

\section{COMPARISONS}

If we may regard ancient Pueblo kivas as of two general types: (1) those with pilasters, for the support of the vaulted roof, rising from a bench-like structure around the inner wall, with wide niches between, such as reached their highest development in the Mesa Verde cliff-dwellings, and (2) those without such pilasters, but with a wide or a narrow bench, sometimes both, around the wall, the two kivas herein discussed belong to the latter type. ${ }^{1}$ This second class of kivas is found especially in the Cañon

${ }^{1}$ This classification should be regarded as general and arbitrary, as it is based solely on the presence or absence of certain very practical structural features, such as pilasters and banquettes. Kivas, however, were designed chiefly for ceremonial uses, hence the occurrence or non-occurrence of a shipapulima, without which certain rites could not be performed, will be of prime importance in the ultimate classification of these ceremonial chambers, based on knowledge still to be gained as a result of more extended research in the ancient Pueblo field.

Fewkes (Cliff Palace, Bull. 51, Bur. Amcr. Ethnol., p. 48, Washington, 1911) clas- 
de Chelly of northeastern Arizona; ${ }^{2}$ in cliff-dwellings of the Navaho National Monument in northern Arizona; ${ }^{3}$ in the Mesa Verde National Park in southwestern Colorado, where it is exemplified in one of the kivas of Cliff Palace; ${ }^{4}$ in the Chaco cañon of northern New Mexico, where it is especially well illustrated in the great kiva excavated by Dr E. L. Hewett at Chettro Kettle ${ }^{5}$ and in others uncovered by Mr Neil M. Judd at Pueblo Bonito; ${ }^{6}$ in the "House of the Great Kiva" at the so-called Aztec ruin in northern New Mexico, brought to light by Mr Morris; $;^{7}$ and in the ruins excavated by Jeançon, Renaud, and Roberts ${ }^{s}$ in the Piedra Parada valley of the upper San Juan of southern Colorado. We may omit from present consideration the rudely built circular chambers unearthed by Mr Judd at Paragonah, Utah, ${ }^{9}$ as these did not contain the chief features that accompany typical Pueblo kivas.

The kivas with the alternating pilasters and wide niches, or "banquettes," appear to represent a higher structural develop-

sifies the twenty-three kivas of Cliff Palace in the Mesa Verde National Park as belonging to two types: (1) "Generally circular or cylindrical subterranean rooms, with pilasters to support the roof, and with fireplace, deflector, and ventilator. (2) Circular ol rectangular rooms with rounded corners, without pilasters, fireplace, or deflector. In the first group may be placed provisionally a subtype (Kiva M, for example) without pilasters, but with a single large banquette. As this subtype is the dominant one in the western part of the San Juan drainage, it may be necessary later to regard it as a type."

2 C. Mindeleff, The Cliff Ruins of Canyon de Chelly, Arizona, Sixteenth Ann. Rep. Bur. Amer. Ethnol., Washington, 1897.

${ }^{3}$ Byron Cummings, Ancient Inhabitants of the San Juan Valley, Bull. Univ. of Utah, JII, no. 3, pt. 2, Salt Lake City, November 1910; J. W. Fewkes, Preliminary Report on a Visit to the Navaho National Monument, Arizona, Bull. 50, Bur. Amer. Ethnol., Washington, 1911.

${ }^{4}$ J. W. Fewkes, Cliff Palace, Bull. 51, Bur. Amer. Ethnol., Washington, 1911.

- Art and Archcoology, xiv, no. 3, Washington, September 1922.

${ }^{6}$ Neil M. Judd in National Geographic Magasine, March, 1922, and additional information kindly furnished by Mr Judd.

${ }^{7}$ Earl H. Morris, Anthropological Papers Amer. Mus. Nat. Hist., xxrv, pt. 1, New York, 1919, and xxvi, pt. 2, New York, 1921.

${ }^{8}$ University of Denver Bulletin, xxis, no. 11, Nov. 1921, and xxir, no. 9, Dec. 1922.

9 Archeological Investigations at Paragonah, Utah, Smithsonian Misc. Coll., Lxx, no. 3, Washington, 1919. 



EARLY POLYCHROME BOWLS $(l, d)$. A CANTEEN WITH PURPLISH GLAZE ON CREAMY SLIP $(c)$. AND A PITCHER QF BLACK (BURNED TO REDDISH-BROWN)-ON-GRAY

(Diameter of $a, 11_{4}^{1} \mathrm{in}$.; height of $c, 73_{8}^{3} \mathrm{in}$.) 

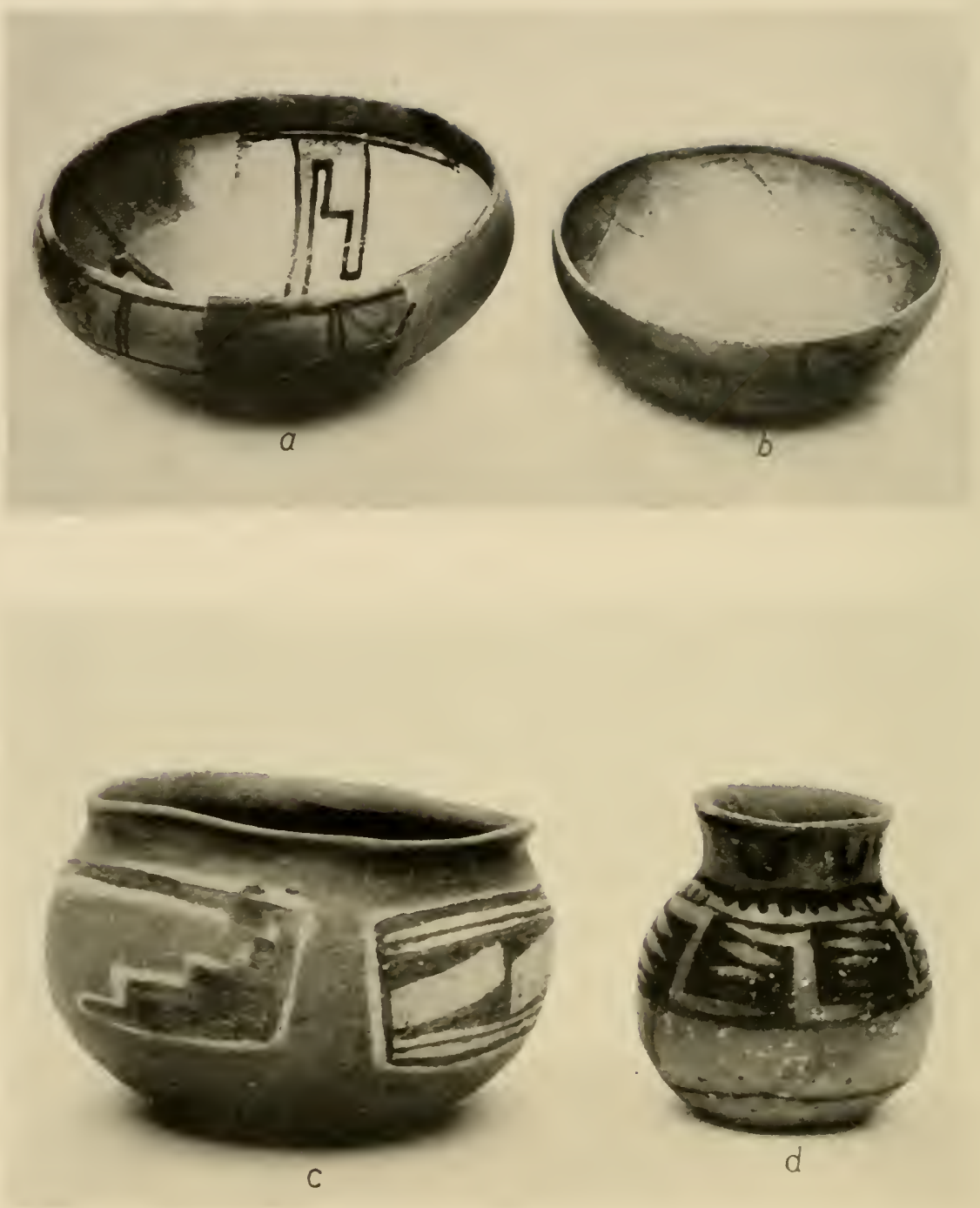

VESSELS OF LATE GLAZE $(a, d)$ AND OF EARLY POLYCHROME $(b, c)$

( $a$, Recent black glaze and mat red on grayish inside, and recent glaze and mat red outside. $b$, Black on red, early polychrome type, the decoration almost faded away. c, Black (bluish) and white on red slip. $d$, Black glaze on red. Diameter of $a, 9 \frac{5}{8}$ in.; heig't of $c, 2 \frac{7}{8}$ in ) 
ment, and therefore perhaps a direct descendant of the more simple type. The former are found especially among the cliff-dwellings of the Mesa Verde and throughout the drainage area of the San Juan. The occurrence of both types of kivas in a single pueblo ${ }^{10}$ or in a group of related pueblos may ultimately be found to indicate that they were built at different periods and that the more elaborate was developed from the simpler. Be that as it may, the persistent and apparently prescribed features of kivas, especially the central fireplace, fire-screen or "deflector," ventilator, and shipapulima, are usually present in both general types. With respect to the relationship of the two forms, it must be said that at least two of the kivas of the second class are very large, that at Chettro Kettle in the Chaco being $62 \frac{1}{2}$ feet and that at the Aztec ruin 48 feet $3 \frac{1}{2}$ inches in diameter, necessitating, as a structural emergency, the use of four great pillars of wood for the supplemental support of the central roof. No such necessity existed in the case of the ancient kivas near Hawikuh.

Among the floor features of each of the kivas at Hawikuh, it will be recalled, was a vault-like structure of unknown function, but there is no evidence whatsoever that either. was used as a fire-pit. The two vaults uncovered by Mr Morris in the House of the Great Kiva at Aztec at first afforded indication that they may have served as fire-pits, but as excavation progressed the contrary was found to be the case. On this point Mr Morris says: $:^{11}$

"The rectangular vaults are an enigma. As they were being excavated, the quantities of charcoal exhumed gave rise to the belief that they were enormous fire-pits. But subsequent examination revealed that the lower limit of the charcoal was considerably above the floors. The fill beneath the fire stratum was of clean sand and dust which had accumulated before the burning of the roof, of which the charcoal was the result. Where the walls were protected they were clean and uncolored by heat. Thus it became evident that whatever the use of the vaults, they were not built as containers for fire."

${ }^{10}$ See G. H. Pepper, Pueblo Bonito, Anthr. Papers Amer. Mrus. Nal. Hist., xxvm, New York, 1920; Judd, op. cit.; Hewetr, op. cit.

1 Morris, Anthr. Papers Amer. M us. Nat. Hist., xxvi, pt. 2, pp. 132-135, New York, 1921. 
The total absence of evidence of fire in either of the vaults of the Hawikuh kivas gives support to Mr Morris' conclusion.

On the other hand, Dr Hewett, ${ }^{12}$ in his preliminary account of Chettro Kettle, expresses the belief that the vaults in the great ceremonial chamber uncovered by him were used as fire-pits:

"On the floor of the circular room are two rectangular pits inclosed in walls of solid masonry. The outer wall of each is more than double the thickness of the inner wall. They were found almost filled with ash and charcoal. Thorough examination of the contents disclosed no bones or other articles that could be identified. Everything that had gone into these fire-boxes had been completely incinerated. The inside dimensions of the pits are roughly $4 \frac{1}{2} \times 8$ feet. They were floored with stone laid in adobe. The height of the pit walls above the floor of the main chamber would average about 15 inches. Their average depth was about $3 \frac{1}{2}$ feet." . . .

"The one [i.e. the kiva] herein described has unquestionably been subjected to great heat, not such as would have been caused merely by the burning out of the roof timbers. The pits in the floor are true fire-vaults, the stone lining being thoroughly baked by long continued heat. They are large enough for the roasting of a whole buffalo, and they would have served perfectly for the incineration of the dead. The adobe floor of the room from the fire-vaults to the wall was in many places thoroughly baked, and the circular walls, especially those of the massive bench and in places the upper zone, were deeply scorched with the heat, even the sandstone under the plaster being browned to a considerable depth below the surface."

With so many indications of the destruction of the Chettro Kettle kiva by fire, and the absence of evidence to show the use of the vaults as fire-pits in the House of the Great Kiva at Aztec and in the kivas near Hawikuh, we may hardly regard as tenable any conclusion that such structures were designed primarily as fire-boxes. Moreover, unless the entire central part of the roof of the kiva ${ }^{13}$ had been open, exposing the chamber to the public

${ }^{12}$ Art and Archaology, op. cit., pp. 123, 125-126.

${ }^{13}$ The four supporting posts of the Chettro Kettle kiva were 26 feet apart, while those of the kiva at the Aztec ruin were 22 to 23 feet apart. Mr Morris presents a sketch plan showing the manner in which the entire kiva described by him was in all probability roofed. 

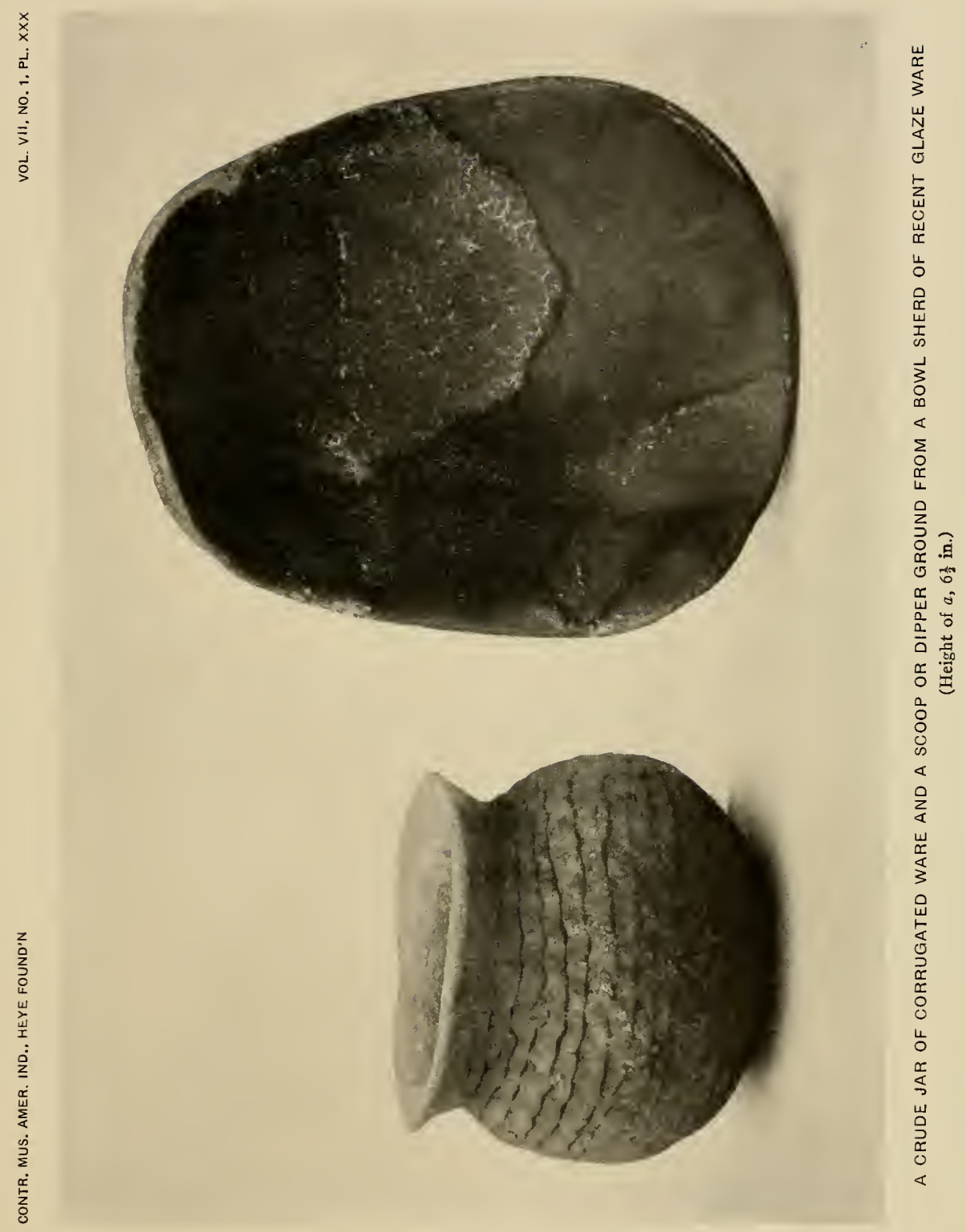

gaze even when the most secret rites were being performed, it would seem to have been impossible to occupy it with a considerable fire burning in either vault, by reason of the smoke; while with a great opening in the middle of the roof the kiva would have been equally uninhabitable in cold or rainy weather. Furthermore, both the Chettro Kettle kiva and the House of the Great Kiva at Aztec were provided with the customary fireplace, as was likewise the case with the kivas near Hawikuh.

As to the direct origin of the kivas near Hawikuh, the most southerly of their kind that have yet been found, we are still in doubt; but evidently they were built by Pueblos who had lived somewhere within the watershed of San Juan river, and, leaving their ancestral home, drifted southward to the present Zuñi valley, doubtless long before the Zuñi themselves established settlements therein, and there lived until stress of circumstance impelled them to continue their migration or to return to their original home. Judging by the pottery from the two kivas and by that found scattered over a considerable distance in the juniper grove north of Hawikuh, on the same elevated spur, the people who occupied the latter site and there buried their dead were of the same culture, if they were not of the same tribe, as those who built the two kivas and the dwellings within its compound. But, as hitherto mentioned, no remains of stone dwellings have been found at the site in the juniper woods, consequently their houses were in all probability of a temporary and perishable character.

There are evidences of another kiva compound, with associated burials of the same nature as those described, about 200 feet northwest of the excavated kivas; and there are surface indications of still others in the immediate vicinity, but as yet only test digging has been done at these sites. 





.

$+2=$

\section{in}

i.

$7 x^{1}-1=$

a

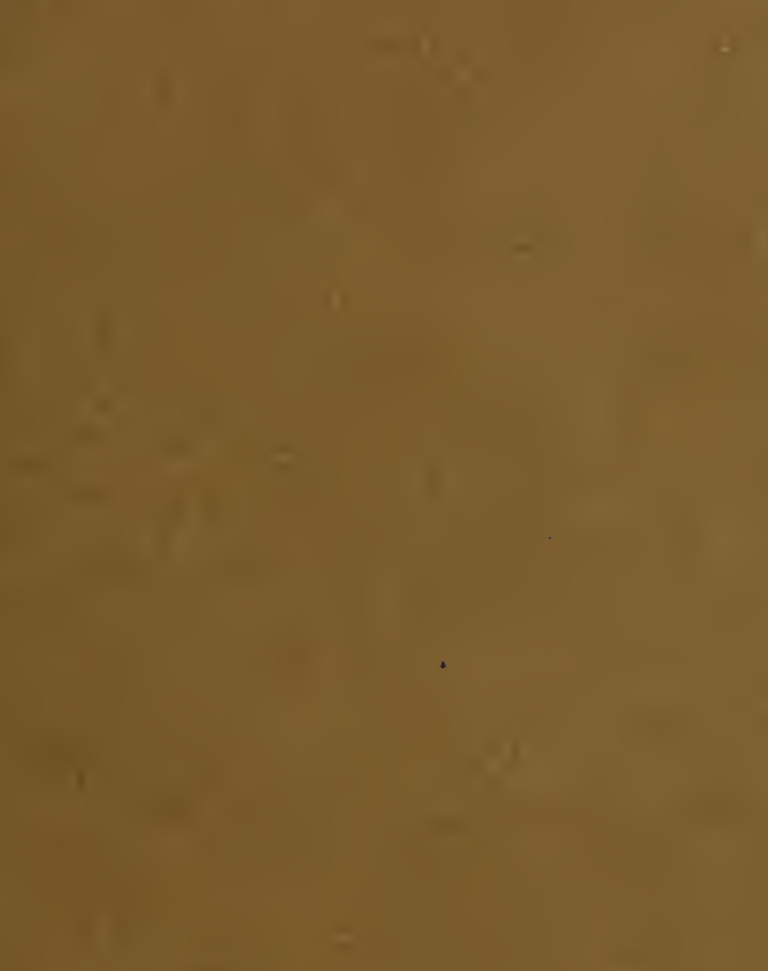

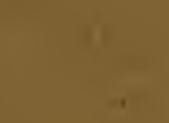

)
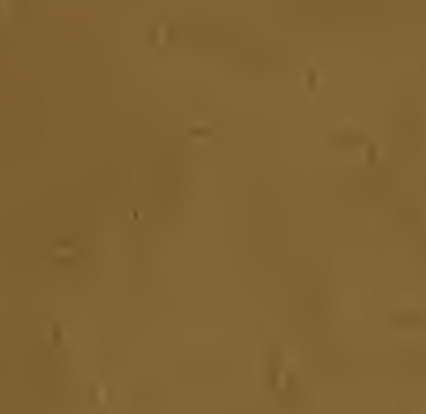

든

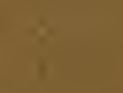

$y=$

(1)

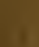

$$
\text { (2) }
$$$$
\text { . }
$$

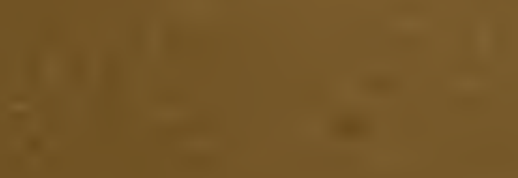$$
\sqrt{2}
$$ 


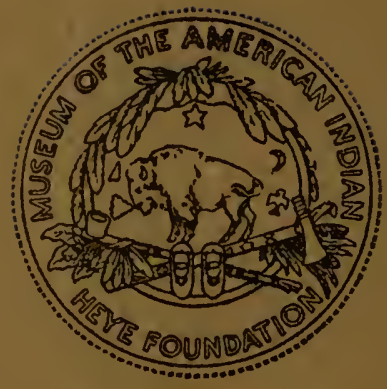

